\title{
PERKEMBANGAN PENELITIAN AKUNTANSI SEKTOR PUBLIK DI INDONESIA
}

\author{
Harumi Puspa Rizky ${ }^{1}$ \\ Fakultas Ekonomi dan Bisnis \\ Universitas Sebelas Maret \\ harumi.puspa@gmail.com
}

\author{
Doddy Setiawan ${ }^{2}$ \\ Fakultas Ekonomi dan Bisnis \\ Universitas Sebelas Maret \\ doddy.setiawan@staff.uns.ac.id
}

\begin{abstract}
ABSTRAK
Penelitian ini bertujuan untuk memberikan gambaran terkait perkembangan penelitian akuntansi sektor publik di Indonesia. Metode yang digunakan dalam penelitian ini adalah charting the field. Sampel yang diambil berasal dari 22 jurnal terakreditasi di Indonesia dan diperoleh 137 artikel selama tahun 2010-2018. Penelitian ini mengklasifikasikan artikel berdasarkan topik dan metode penelitian. Hasil penelitian ini menunjukkan bahwa topik yang paling banyak digunakan dalam penelitian akuntansi sektor publik adalah topik mengenai akuntansi keuangan dan untuk model yang sering digunakan adalah metode kuantitatif dan juga metode survei serta archival. Topik akuntansi keuangan pada sektor publik menjadi topik terbanyak yang diteliti dikarenakan akuntansi pada sektor publik masih menjadi perhatian khusus dan masih banyak pemerintah daerah yang terkendala pelaporan keuangan. Sementara itu dari topik penelitian yang paling sedikit dilakukan dari tujuh kategori adalah topik mengenai perpajakan dan sistem akuntansi.
\end{abstract}

Kata Kunci : Akuntansi sektor publik; charting the field; penelitian akuntansi.

\begin{abstract}
This study aims to provide an overview of the development of public sector accounting research in Indonesia. The method used in this research is charting the field. Samples taken came from 22 accredited journals of Indonesia and 137 articles written during 2010-2018. This study classifies articles based on research topics and methods. The results of this study indicate that the topic most widely used in public sector accounting research is the topic of financial accounting and for models that are often used are quantitative methods as well as survey and archival methods. The topic of financial accounting in the public sector is the most researched topic because accounting in the public sector is still a particular concern and many local governments are constrained by financial reporting. Meanwhile, from the research topics, at least seven of the categories were taxation and accounting systems.
\end{abstract}

Keywords : $\quad$ Public sector accounting; charting the field; accounting research.

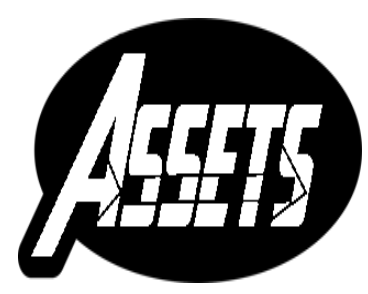

ASSETS

Jurnal Akuntansi dan Pendidikan

Vol. 8 No. 2

Hlmn. 94-116

Madiun, Oktober 2019

p-ISSN: 2302-6251

e-ISSN: 2477-4995

Artikel masuk:

8 Juli 2019

Tanggal diterima: 16 September 2019 


\section{PENDAHULUAN}

Tuntutan mengenai akuntabilitas keuangan, efisiensi, dan dan efektivitas dalam sektor publik membuat organisasi sektor publik di dunia mengalami perubahan. Perubahan tersebut adalah dari sistem tradisional yang mempunyari ciriciri bahwa penyusunan anggaran bersifat incrementalism, menggunakan line-item dan cenderung sentalistis yang terkesan kaku menjadi sistem yang fleksibel (Usman, Sunandar, \& Farida, 2014). Perubahan ini dikenal dengan New Public Management (NPM). Hal ini merupakan tindak lanjut dari peraturan pemerintah mengenai otonomi daerah di mana daerah diberi wewenang untuk menjalankan dan mengurus urusan pemerintah serta pelayanan masyarakat sesuai undang-undang yang berlaku.

Di Indonesia, peraturan mengenai perubahan ke NPM dimulai ketika pemerintah mengeluarkan Undang-Undang mengenai keuangan Negara yaitu UU No. 17 Tahun 2003, UU No. 1 Tahun 2004 mengenai perbendaharaan Negara, dan UU No. 15 Tahun 2004 tentang Pemeriksaan Pengelolaan dan Tanggung Jawab Keuangan Negara. Salah satu yang diatur adalah pada UU No 17 Tahun 2003 yang mewajibkan adanya Standar Akuntansi Pemerintahan (SAP) sebagai basis penyusunan akuntansi di Indonesia (Usman et al., 2014). SAP tersebut termuat dalam PP No 71 Tahun 2010 dan juga menyatakan perubahan sistem akuntansi berbasis kas ke sistem akuntansi berbasis akrual. Perubahan ini diharapkan akan dapat meningkatkan transparansi dan akuntabilitas pengelolaan keuangan Negara serta mengikuti international best practices yang disesuaikan dengan kondisi yang ada di Indonesia (Satrio, Yuhertiana, \& Hamzah, 2016). Pengelolaan keuangan dengan menggunakan akuntansi merupakan hal penting dalam reformasi pengelolaan keuangan sebuah Negara, baik itu pusat maupun daerah dimana akuntansi akan menghasilkan output berupa informasi laporan keuangan (Tresnawati \& Setiawan, 2013).

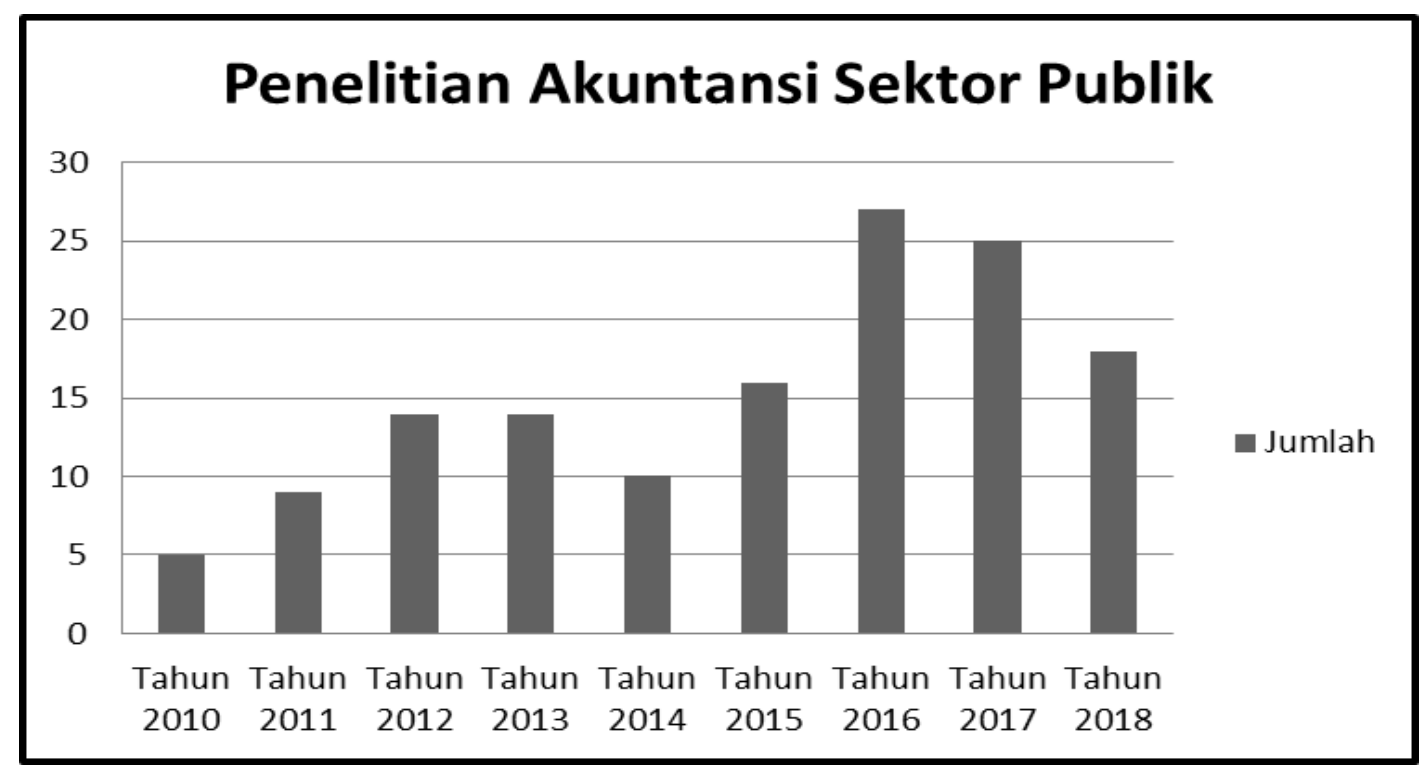

Gambar 1. Diagram perkembangan penelitian akuntansi sektor publik

Beberapa tahun belakangan ini penelitian mengenai akuntansi sektor publik mulai menarik perhatian banyak pihak. Hal ini dibuktikan dengan meningkatnya penelitian di sektor publik pada jurnal-jurnal terakreditasi di Indonesia. Penelitian mengenai akuntansi sektor publik telah banyak diteliti di Indonesia maupun di Luar 
negeri. Gambar 1 menunjukkan peningkatan penelitian akuntansi yang dilakukan di Indonesia sejak tahun 2010-2018. Meskipun terlihat mengalami penurunan dari tahun 2016, namun secara keseluruhan penelitian akuntansi sektor publik semakin banyak dilakukan di Indonesia. Hal itu juga membuktikan bahwa pengetahuan akan sektor publik sangatlah penting. Topik yang dibahas pada sektor publik semakin banyak dari tahun ke tahun seiring dengan berkembangnya penelitian di Indonesia dan adanya jurnal-jurnal terakreditasi dan tentunya perubahan peraturan mengenai sistem akuntansi. Hal inilah yang memotivasi penulis untuk meneliti mengenai perkembangan penelitian akuntansi sektor publik di Indonesia seiring dengan perkembangan akuntansi pemerintahan.

Penelitian ini juga termotivasi oleh penelitian yang dilakukan oleh Hesford et al. (2007) yang meneliti mengenai bibliografi di bidang akuntansi manajemen. Di Indonesia penelitian dengan model serupa juga dilakukan oleh Dewi, Fitriana and Setiawan (2018) mengenai pengungkapan di Indonesia. Selain itu, Herawati and Bandi (2017) meneliti mengenai akuntansi perpajakan dengan metode yang serupa. Pada penelitian ini peneliti mengkaji dengan menggunakan hasil penelitian dari 137 artikel tentang akuntansi sektor publik pada 22 jurnal terakreditasi di Indonesia per Maret 2019. Artikel yang dipilih merupakan artikel yang terbit selama tahun 2010-2018. Jurnal terakreditasi dipilih sebagai objek pengamatan dikarenakan telah melalui seleksi yang ketat sehingga artikel mempunyai kualitas dan kredibilitas yang baik. Oleh karena itu, tujuan dari penelitian ini adalah untuk mengetahui perkembangan penelitian mengenai akuntansi sektor publik di Indonesia.

\section{METODE PENELITIAN}

Metode yang digunakan dalam penelitian ini adalah metode "charting the field" yang dikembangkan oleh Hesford et al. (2007). Pada penelitian ini, peneliti memilih beberapa hasil penelitian mengenai akuntansi sektor publik yang diterbitkan di 22 jurnal terakreditasi per Maret 2019, kemudian mengidentifikasi berdasarkan topik dan metode. Jurnal yang terpilih merupakan jurnal terakreditasi pada sinta 2 per Maret tahun 2019 dengan kata kunci akuntansi, bisnis, dan business. Daftar jurnal yang digunakan oleh peneliti dapat dilihat pada tabel 2. Artikel yang dipilih dalam artikel ini berdasarkan penelitian pada tahun 2010-2018 yang berarti penelitian ini menggunakan artikel tentang akuntansi sektor publik dalam kurun waktu 9 tahun dan tersedia online. Penelitian ini akan membagi penelitian dalam dua dekade yaitu dekade tahun 2010-2014 dan dekade tahun 2015-2018. Dari proses seleksi dan indentifikasi artikel akuntansi sektor publik dari 22 jurnal terakreditasi pada sinta2 diperoleh 137 artikel.

Tahapan pada proses pemilihan artikel dalam penelitian ini adalah peneliti mencari data mengenai jurnal yang terakreditasi pada laman sinta 2 milik kemenristekdikti dengan kata kunci akuntansi, bisnis, dan business. Dari ketiga kata kunci tersebut diperoleh 22 jurnal yang terakreditasi yang selanjutnya peneliti membuka lamannya satu per satu. Pada setiap laman jurnal peneliti memasukkan kata kunci "sektor publik" dan "pemerintah" pada kolom pencarian. Selanjutnya apabila pada satu jurnal tidak ditemukan artikel mengenai akuntansi sektor publik maka tidak dimasukkan dalam populasi penelitian dan apabila ditemukan penelitian mengenai akuntansi sektor publik maka peneliti mengunduh setiap artikel. Setelah semua 
diunduh maka selanjutnya adalah mengidentifikasi setiap artikel berdasarkan jurnal, judul, tahun, penulis dan juga variabel yang digunakan.

Pada tabel 3 menunjukkan bahwa artikel yang digunakan dalam penelitian ini terdiri dari 22 jurnal dalam periode 13 tahun yaitu dari tahun 2010-2018. Jurnal yang paling mendominasi dan menerbitkan banyak penelitian mengenai sektor publik adalah JAMAL dengan 20\%. Bahkan dalam tahun 2010-2014 ataupun 2015-2018 JAMAL tetap mendominasi. JAAI memperoleh $9 \%$ disusul JAB, JAI, dan JDA yang mempunyai persentase yang sama yaitu 8\% namun JAB dalam kurun waktu 2010-2014 tidak menerbitkan artikel sektor publik sementara untuk JAAI dan JAI masing-masing menerbitkan 3 artikel pada 2010-2018 dan 11 pada tahun 2015-2018. Dari 22 jurnal terakreditasi yang terpilih pada penelitian ini, sebanyak 17 jurnal mengalami peningkatan dalam penerbitan artikel mengenai sektor publik, dan 5 jurnal lainnya mengalami penurunan. Kelima jurnal tersebut adalah JIAB, MRAAI, JMSBK, JSB, dan JEP. Namun, secara keseluruhan penelitian mengenai sektor publik di Indonesia pada jurnal terakreditas mengalami kenaikan. Terutama pada dekade kedua. Terlihat dalam tabel bahwa pada dekade pertama tahun 2010-2014 terdapat 44 penelitian, sementara itu pada dekade kedua tahun 2015-2018 terdapat 109 penelitian yang diterbitkan. Data tersebut menunjukkan bahwa penelitian mengenai sektor publik menarik untuk diteliti meski pada beberapa jurnal masih sedikit penelitian mengenai ini.

Tabel 1. Penelitian Akuntansi Sektor Publik

Jurnal Penulis (Tahun)

Jurnal Akuntansi dan Junaidi (2010), Hasniasari \& Sholihin (2014), Satrio et al. (2016),

Keuangan Herwiyanti et al. (2017), Djamhuri \& Rosidi (2017).

Jurnal Akuntansi dan Rahman (2011), Arifin et al. (2010), Soleman (2013), Auditing Indonesia Nurhidayati \& Yaya (2013), Afdalia et al. (2014), Yuhertiana et al. (2012), Sofyani \& Akbar (2015), Ratmono \& Suryani (2016), Setiono \& Hapsoro (2016), Abdullah \& Muthia (2017), Ahyaruddin \& Akbar (2017), Muhtar et al. (2017).

Jurnal Akuntansi dan Amalia et al. (2015), Taufik \& Bandi (2015), Solikin (2016), Bisnis Parananda (2016), Trisaptya et al. (2016), Purwanto (2016), Prabowo (2016), Ferdiansyah (2016), Pratomo (2016), Istiyanto (2016), Alhajjriana et al. (2017).

Jurnal Akuntansi dan Arifin \& Pratolo (2012), Usman et al. (2014), Firdaus et al Investasi (2010), Mudhofar \& Tahar (2016), Hadi \& Handajani (2017), Sutaryo \& Sinaga (2018), Yuliani \& Susanto (2018), Andika et al. (2012).

Jurnal Akuntansi dan Setyaningrum \& Syafitri (2012), Sofyani \& Akbar (2013), Keuangan Indonesia Winoto \& Falikhatun (2015), Suryono \& Chariri (2016), Zulaikha \& Hadiprajitno (2016).

Jurnal Akuntansi Fitri \& Indriani (2011), Rahmanti \& Prastiwi (2011), Anggraini Multiparadigma \& Setiawan (2011), Hasiara (2012), Rimawati (2012), Ratnafuri \& Herawati (2012), Tresnawati \& Setiawan (2013), Setiawaty (2013), Yanida, Sudarma, \& Rahman (2013), Shariha (2014), Randa \& Daromes (2014), Zamzami \& Faiz (2015), Gamar \& Djamhuri (2015), Ratmono \& Pradopowati (2016), Verawaty et 


\begin{tabular}{|c|c|}
\hline Jurnal & Penulis (Tahun) \\
\hline $\begin{array}{l}\text { Jurnal } \\
\text { Akuntansi }\end{array}$ & $\begin{array}{l}\text { al. (2016), Siddi (2016), Biswan \& Wardani (2017), Darmayasa } \\
\text { (2017), Andhayani (2017), Satriayaja et al. (2017), Pahlevi \& } \\
\text { Setiawan (2017), Purwanti (2018), Subadriyah (2017), Kurniati } \\
\text { et al. (2017), Wijayanti \& Hanafi (2018), Gunawan \& Nurulita } \\
\text { (2017), Ratmono \& Rochmawati (2018), Rahayu (2018). } \\
\text { Subowo \& Wati (2010), Suryarini \& Anwar (2010), Ulum } \\
\text { (2011), Yustrianthe (2012), Kurrohman (2013), Fitri et al. (2013), } \\
\text { Surepno (2015), Nugraheni \& Murtini (2015), Surastiani \& } \\
\text { Handayani (2015). }\end{array}$ \\
\hline $\begin{array}{l}\text { Jurnal Ilmiah } \\
\text { Akuntansi dan Bisnis }\end{array}$ & $\begin{array}{l}\text {, Prastiwi \& Satyawan (2014), Sofyani \& Prayudi } \\
\text { druzaman \& Chairunnisa (2011), Aryawati \& Sudana } \\
\text { diartha (2010). }\end{array}$ \\
\hline $\begin{array}{l}\text { Riset Akuntansi dan } \\
\text { Keuangan Indonesia } \\
\text { Media Riset Akuntansi, } \\
\text { Auditing \& Informasi }\end{array}$ & $\begin{array}{l}\text { lfikar (2016), Octariani et al. (2017), Purbasari \& } \\
\text { ). } \\
\text { i (2018). }\end{array}$ \\
\hline Jurnal Akuntansi & tafien (2018). \\
\hline $\begin{array}{l}\text { Jurnal Akuntansi dan } \\
\text { Pendidikan }\end{array}$ & $\begin{array}{l}\text { Ambaarwati \& Payamta (2015), Hidayati \& Djuminah (2013), } \\
\text { Anggraini \& Nuraina (2014), Harumiati \& Payamta (2014), } \\
\text { Saraswati, Budiwibowo, \& Sulistyowati (2017), Juliana \& } \\
\text { Widhianningrum (2017), Nugroho \& Prasetyo (2018). }\end{array}$ \\
\hline $\begin{array}{l}\text { Istishadia Jurnal Kajian } \\
\text { Ekonomi dan Bisnis } \\
\text { Jurnal Aplikasi Bisnis } \\
\text { dan Manajemen }\end{array}$ & , Terminanto \\
\hline $\begin{array}{l}\text { Jurnal Ekonomi dan } \\
\text { Bisnis }\end{array}$ & $\begin{array}{l}\text { Ismail et al. (2016), Pandansari (2016), Hasthoro \& Sunardi } \\
\text { (2016), Widagdo \& Munir (2017), Kamaludin \& Usman (2018), } \\
\text { Butar \& Perdana (2017), Diptyana \& Rokhmania (2018), } \\
\text { Erawati \& Kurniawan (2018), Wibisono et al. (2018). }\end{array}$ \\
\hline $\begin{array}{l}\text { Jurnal Manajemen, } \\
\text { Strategi Bisnis, dan } \\
\text { Kewirausahaan }\end{array}$ & \\
\hline $\begin{array}{l}\text { Jurnal Siasat Bisnis } \\
\text { Journal of Indonesian } \\
\text { Economy and Business }\end{array}$ & $\begin{array}{l}\text { Kirana \& Saleh (2011), Ahyaruddin \& Akbar (2017), Bawono \& } \\
\text { Halim (2015), Novriansa \& Sugiyanto (2016), Wijaya \& Akbar } \\
\text { (2013). }\end{array}$ \\
\hline $\begin{array}{l}\text { Journal of Econ } \\
\text { and Policy }\end{array}$ & Malik (2014), Riyardi \& Widojono (2011). \\
\hline $\begin{array}{l}\text { Jurnal Ekonomi } \\
\text { Pembangunan }\end{array}$ & \\
\hline $\begin{array}{l}\text { Jurnal Ekonomi dan } \\
\text { Pembangunan }\end{array}$ & $\mathrm{N}$ \\
\hline $\begin{array}{l}\text { Kajian Ekonomi } \\
\text { Keuangan (Kemenkeu) }\end{array}$ & $\begin{array}{l}\text { Aziz et al. (2013), Azwar (2016), Sumando et al. (2018), } \\
\text { Setiawan \& Setyorini (2018). }\end{array}$ \\
\hline
\end{tabular}




\section{HASIL PENELITIAN DAN PEMBAHASAN Klasifikasi Artikel}

Pada artikel ini, peneliti mengelompokkan setiap artikel pada dua klasifikasi yaitu topik dan metode penelitian dengan mengacu pada penelitian sebelumnya (Hesford et al., 2007). Penelitian ini menggunakan 137 artikel dari 22 jurnal terakreditasi nasional. Penelitian ini dilakukan pada artikel yang terbit dalam kurun waktu 9 tahun dari tahun 2010-2018 karena pada tahun-tahun tersebut penelitian mengenai akuntansi sektor publik mulai berkembang di Indonesia. Hal ini dapat dibuktikan dengan data yang dikumpulkan oleh peneliti pada 22 jurnal terakreditasi. Meskipun dalam dekade pertama, penelitian mengenai akuntansi sektor publik cenderung naik turun, namun dalam 4 tahun terakhir mengalami peningkatan yang cukup signifikan. Hal itu mungkin juga disebabkan oleh pergantian peraturan pemerintah menjadi akrual dalam PP No. 71 tahun 2011 dimana pada tahun 2015 pemerintah daerah diwajibkan untuk menggunakan sistem akuntansi berbasis akrual.

\section{Klasifikasi berdasarkan Topik Pembahasan}

Penelitian ini mengklasifikasin setiap artikel berdasarkan topik dan metode penelitian. Topik penelitian dikelompokkan menjadi empat kelompok yaitu sistem akuntansi, akuntansi keuangan, akuntansi manajemen, regulasi, audit, pajak dan topik lainnya. Tabel 4 menunjukkan bahwa $45 \%$ artikel akuntansi sektor publik didominasi oleh topik akuntansi keuangan. Sistem akuntansi 6\%, akuntansi manajemen 10\%, regulasi $9 \%$, audit $16 \%$, perpajakan $5 \%$, lain-lain sebesar $9 \%$. Topik yang termasuk dalam kategori sistem akuntansi adalah Sistem Pengendalian Internal (SPI), EGovernment, Implementasi SAKIP, Sistem Informasi, Sistem Akuntansi Pemerintah dan Implementasi sistem E-Procurement. Dari keenam kategori topik sistem akuntansi sektor publik tersebut, SPI, E-Government dan Implementasi SAKIP mendominasi, namun secara keseluruhan keenamnya merata.

Topik yang masuk dalam kategori akuntansi keuangan adalah sebanyak 37 kategori. Dari 37 topik tersebut pengungkapan laporan keuangan, akuntabilitas kinerja, dan flypaper effect paling mendominasi dengan masing-masing 3\%. Topik penelitian yang termasuk dalam akuntansi manajemen adalah kinerja aparatur pemerintah, balancescorecard, performance measurement system, penganggaran berbasis kinerja, penerapan just in time, dan pengukuran kinerja. Dari keenam kategori tersebut kinerja aparatur pemerintah adalah yang paling mendominasi dengan persentase sebesar $21.14 \%$.

Topik penelitian mengenai regulasi mempunyai 2 kategori yaitu implementasi PP No.71 tahun 2010 dan SAP 24. Dari keduanya implementasi PP No. 71 tahun 2010 adalah yang paling mendominasi dengan persentase sebesar $8 \%$ atau terdapat 12 penelitian. PP ini merupakan peraturan mengenai akuntansi berbasis akrual dimana pemerintah harus menerapkannya mulai tahun 2015. Dari kedua belas itu pula, semuanya merupakan penelitian antara tahun 2015-2018. Jadi, dapat diketahui bahwa perubahan akuntansi ke akrual ini membuat banyak peneliti tertarik.

Kategori yang termasuk dalam topik audit sektor publik adalah 10 kategori yaitu kualitas audit, opini audit, kinerja audit, peran audit dalam pemberantasan korupsi, audit, fraud, determinan tingkat penyimpangan, pelaporan pelanggaran, mendeteksi kecurangan, dan konflik peran pada auditor internal. Dari kesepuluh 
kategori tersebut, kualitas audit dan opini audit merupakan kategori topik yang paling sering diteliti. Topik perpajakan paada akuntansi sektor publik terdapat tujuh kategori yaitu pemotongan dan pemungutan pajak, amnesti pajak, dampak PP terhadap penerimaan pajak, pajak bumi dan bangunan, pajak penghasilan, sunset policy, dan penerimaan PPH dan PPN. Dari ketujuh kategori topik tersebut, pemotongan dan pemungutan pajak adalah yang paling sering diteliti. Topik penelitian lain-lain terdiri dari tiga belas kategori dan semuanya memiliki persentase $1 \%$.

Tabel 2. Daftar Jurnal yang Digunakan

\begin{tabular}{|c|c|c|c|}
\hline Jurnal & Kepanjangan Nama Jurnal & Institusi & Jumlah \\
\hline JAK & Jurnal Akuntansi dan Keuangan & $\begin{array}{l}\text { Universitas Kristen Petra } \\
\text { Surabaya }\end{array}$ & 6 \\
\hline JAAI & $\begin{array}{l}\text { Jurnal Akuntansi dan Auditing } \\
\text { Indonesia }\end{array}$ & Universitas Islam Indonesia & 12 \\
\hline $\mathrm{JAB}$ & Jurnal Akuntansi dan Bisnis & Universitas Sebelas Maret & 13 \\
\hline JAI & Jurnal Akuntansi dan Investasi & $\begin{array}{l}\text { Universitas Muhammadiyah } \\
\text { Yogyakarta }\end{array}$ & 11 \\
\hline JAKI & $\begin{array}{l}\text { Jurnal Akuntansi dan Keuangan } \\
\text { Indonesia }\end{array}$ & Universitas Indonesia & 5 \\
\hline JAMAL & $\begin{array}{l}\text { Jurnal Akuntansi } \\
\text { Multiparadigma }\end{array}$ & Universitas Brawijaya & 32 \\
\hline JDA & Jurnal Dinamika Akuntansi & Universitas Negeri Semarang & 9 \\
\hline JIAB & $\begin{array}{l}\text { Jurnal Ilmiah Akuntansi dan } \\
\text { Bisnis }\end{array}$ & $\begin{array}{l}\text { Fakultas Ekonomi dan Bisnis } \\
\text { Universitas Udayana }\end{array}$ & 6 \\
\hline RAKI & $\begin{array}{l}\text { Riset Akuntansi dan Keuangan } \\
\text { Indonesia }\end{array}$ & $\begin{array}{l}\text { Universitas Muhammadiyah } \\
\text { Surakarta }\end{array}$ & 3 \\
\hline MRAAI & $\begin{array}{l}\text { Media Riset Akuntansi, Auditing } \\
\text { \& Informasi }\end{array}$ & Universitas Trisakti & 1 \\
\hline JA & Jurnal Akuntansi & Universitas Tarumanegara & 2 \\
\hline ASSETS & Jurnal Akuntansi dan Pendidikan & Universitas PGRI Madiun & 7 \\
\hline IJKEB & $\begin{array}{l}\text { Istishadia Jurnal Kajian Ekonomi } \\
\text { dan Bisnis }\end{array}$ & STAIN Kudus & 2 \\
\hline JABM & $\begin{array}{l}\text { Jurnal Aplikasi Bisnis dan } \\
\text { Manajemen }\end{array}$ & Institut Pertanian Bogor & 1 \\
\hline JEB & Jurnal Ekonomi dan Bisnis & $\begin{array}{l}\text { Universitas Kristen Satya } \\
\text { Wacana }\end{array}$ & 9 \\
\hline JMSBK & $\begin{array}{l}\text { Jurnal Manajemen, Strategi } \\
\text { Bisnis, dan Kewirausahaan }\end{array}$ & Universitas Udayana & 1 \\
\hline JSB & Jurnal Siasat Bisnis & Universitas Islam Indonesia & 2 \\
\hline JIEB & $\begin{array}{l}\text { Journal of Indonesian Economy } \\
\text { and Business }\end{array}$ & Universitas Gadjah Mada & 5 \\
\hline JEJAK & Journal of Economics and Policy & Universitas Negeri Semarang & 2 \\
\hline
\end{tabular}


RIZKY, HP \& SETIAWAN, D.

\begin{tabular}{|c|c|c|c|}
\hline Jurnal & Kepanjangan Nama Jurnal & Institusi & Jumlah \\
\hline JEP & Jurnal ekonomi Pembangunan & $\begin{array}{l}\text { Universitas Muhammadiyah } \\
\text { Surakarta }\end{array}$ & 1 \\
\hline JEPI & $\begin{array}{l}\text { Jurnal Ekonomi dan } \\
\text { Pembangunan Indonesia }\end{array}$ & Universitas Indonesiaa & 2 \\
\hline KEK & $\begin{array}{l}\text { Kajian Ekonomi Keuangan } \\
\text { (Kemenkeu) }\end{array}$ & Kementerian Keuangan & 5 \\
\hline
\end{tabular}

Tabel 3. Jumlah dan Persentase Jurnal dalam Penelitian Akuntansi Sektor Publik

\begin{tabular}{lrrrrrr}
\hline \multirow{2}{*}{ Nama Jurnal } & \multicolumn{2}{c}{$\mathbf{2 0 1 0 - 2 0 1 8}$} & \multicolumn{2}{c}{$\mathbf{2 0 1 0 - 2 0 1 4}$} & \multicolumn{2}{c}{$\mathbf{2 0 1 5 - 2 0 1 8}$} \\
\cline { 2 - 8 } Jumlah & \multicolumn{1}{c}{$\%$} & Jumlah & \multicolumn{1}{c}{ \% } & Jumlah & \multicolumn{1}{c}{$\mathbf{0}$} \\
\hline JAK & 6 & $4 \%$ & 3 & $6 \%$ & 3 & $3 \%$ \\
JAAI & 12 & $9 \%$ & 5 & $10 \%$ & 7 & $8 \%$ \\
JAB & 13 & $9 \%$ & 0 & $0 \%$ & 13 & $15 \%$ \\
JAI & 11 & $8 \%$ & 5 & $10 \%$ & 6 & $7 \%$ \\
JAKI & 5 & $4 \%$ & 2 & $4 \%$ & 3 & $3 \%$ \\
JAMAL & 32 & $22 \%$ & 13 & $25 \%$ & 19 & $22 \%$ \\
JDA & 9 & $7 \%$ & 6 & $12 \%$ & 3 & $3 \%$ \\
JIAB & 6 & $4 \%$ & 4 & $8 \%$ & 2 & $2 \%$ \\
RAKI & 3 & $2 \%$ & 0 & $0 \%$ & 3 & $3 \%$ \\
MRAAI & 1 & $1 \%$ & 0 & $0 \%$ & 1 & $1 \%$ \\
JA & 2 & $1 \%$ & 0 & $0 \%$ & 2 & $2 \%$ \\
ASSETS & 7 & $5 \%$ & 3 & $6 \%$ & 4 & $5 \%$ \\
IJKEB & 2 & $1 \%$ & 0 & $0 \%$ & 2 & $2 \%$ \\
JABM & 1 & $1 \%$ & 0 & $0 \%$ & 1 & $1 \%$ \\
JEB & 9 & $7 \%$ & 0 & $0 \%$ & 9 & $10 \%$ \\
JMSBK & 1 & $1 \%$ & 1 & $2 \%$ & 0 & $0 \%$ \\
JSB & 2 & $1 \%$ & 2 & $4 \%$ & 0 & $0 \%$ \\
JIEB & 5 & $4 \%$ & 2 & $4 \%$ & 3 & $3 \%$ \\
JEJAK & 2 & $1 \%$ & 2 & $4 \%$ & 0 & $0 \%$ \\
JEP & 1 & $1 \%$ & 1 & $2 \%$ & 0 & $0 \%$ \\
JEPI & 2 & $1 \%$ & 1 & $2 \%$ & 1 & $1 \%$ \\
KEK & 5 & $4 \%$ & 1 & $2 \%$ & 4 & $5 \%$ \\
\hline TOTAL & $\mathbf{1 3 7}$ & & $\mathbf{5 1}$ & & $\mathbf{8 6}$ & $\mathbf{1}$ \\
\hline
\end{tabular}

\section{Klasifikasi berdasarkan Metode Penelitian}

Penelitian ini mengklasifikasikan metode penelitian menjadi dua kategori. Kategori pertama yaitu kualitatif, kuantitatif dan campuran disajikan dalam tabel 4 . Sementara itu, kategori kedua mencakup metode eksperimen, survei, archival, kajian pustaka, studi kasus, deskriptif, interpretif, fenomenologi dan lain-lain disajikan dalam tabel 5. Pada tabel 5 dapat terlihat bahwa metode kualitatif masih sedikit digunakan dalam penelitian sektor publik dengan $28 \%$ dibandingkan dengan metode kuantitatif yang mempunyai persentase sebesar $70 \%$. 
Tabel 4. Metode Penelitian - Jurnal

\begin{tabular}{|c|c|c|c|c|c|c|c|c|c|}
\hline \multirow[b]{2}{*}{$\begin{array}{l}\text { Nama } \\
\text { Jurnal }\end{array}$} & \multicolumn{3}{|c|}{ Kualitatif } & \multicolumn{3}{|c|}{ Kuantitatif } & \multicolumn{3}{|c|}{ Campuran } \\
\hline & $\begin{array}{c}2010- \\
2014 \\
\end{array}$ & $\begin{array}{l}2015- \\
2018 \\
\end{array}$ & $\begin{array}{c}2010- \\
2018\end{array}$ & $\begin{array}{c}2010- \\
2014\end{array}$ & $\begin{array}{c}2015- \\
2018 \\
\end{array}$ & $\begin{array}{l}2010- \\
2018 \\
\end{array}$ & $\begin{array}{c}2010- \\
2014 \\
\end{array}$ & $\begin{array}{l}2015- \\
2018 \\
\end{array}$ & $\begin{array}{l}2010- \\
2018\end{array}$ \\
\hline JAK & $0(0 \%)$ & $2(8 \%)$ & $2(5 \%)$ & $3(8 \%)$ & $1(2 \%)$ & $4(4 \%)$ & $0(0 \%)$ & $0(0 \%)$ & $0(0 \%)$ \\
\hline JAAI & $1(8 \%)$ & $2(8 \%)$ & $3(8 \%)$ & $4(11 \%)$ & $3(5 \%)$ & $7(7 \%)$ & $0(0 \%)$ & $2(67 \%)$ & $2(50 \%)$ \\
\hline JAB & $0(0 \%)$ & $0(0 \%)$ & $0(0 \%)$ & $0(0 \%)$ & $13(22 \%)$ & $13(13 \%)$ & $0(0 \%)$ & $0(0 \%)$ & $0(0 \%)$ \\
\hline JAI & $0(0 \%)$ & $2(8 \%)$ & $2(5 \%)$ & $5(13 \%)$ & $4(7 \%)$ & $9(9 \%)$ & $0(0 \%)$ & $0(0 \%)$ & $0(0 \%)$ \\
\hline JAKI & $0(0 \%)$ & $0(0 \%)$ & $0(0 \%)$ & $2(5 \%)$ & $3(5 \%)$ & $5(5 \%$ & $0(0 \%)$ & $0(0 \%)$ & $0(0 \%)$ \\
\hline JAMAL & $6(50 \%)$ & $11(46 \%)$ & $17(47 \%)$ & $7(18 \%)$ & $8(14 \%)$ & $15(15 \%$ & $0(0 \%)$ & $0(0 \%)$ & $0(0 \%)$ \\
\hline JDA & $1(8 \%)$ & $1(4 \%)$ & $2(6 \%)$ & $5(13 \%)$ & $2(3 \%)$ & $7(7 \%)$ & $0(0 \%)$ & $0(0 \%)$ & $0(0 \%)$ \\
\hline JIAB & $3(25 \%)$ & $0(0 \%)$ & $3(8 \%)$ & $1(3 \%)$ & $2(3 \%)$ & $3(3 \%)$ & $0(0 \%)$ & $0(0 \%)$ & $0(0 \%)$ \\
\hline RAKI & $0(0 \%)$ & $0(0 \%)$ & $0(0 \%)$ & $0(0 \%)$ & $3(5 \%)$ & $3(3 \%)$ & $0(0 \%)$ & $0(0 \%)$ & $0(0 \%)$ \\
\hline MRAAI & $0(0 \%)$ & $1(4 \%)$ & $1(3 \%)$ & $0(0 \%)$ & $0(0 \%)$ & $0(0 \%)$ & $0(0 \%)$ & $0(0 \%)$ & $0(0 \%)$ \\
\hline JA & $0(0 \%)$ & $0(0 \%)$ & $0(0 \%)$ & $0(0 \%)$ & $2(3 \%)$ & $2(2 \%)$ & $0(0 \%)$ & $0(0 \%)$ & $0(0 \%)$ \\
\hline ASSETS & $0(0 \%)$ & $2(8 \%)$ & $2(6 \%)$ & $3(8 \%)$ & $2(3 \%)$ & $5(5 \%)$ & $0(0 \%)$ & $0(0 \%)$ & $0(0 \%)$ \\
\hline IJKEB & $0(0 \%)$ & $0(0 \%)$ & $0(0 \%)$ & $0(0 \%)$ & $2(3 \%)$ & $2(2 \%)$ & $0(0 \%)$ & $0(0 \%)$ & $0(0 \%)$ \\
\hline JABM & $0(0 \%)$ & $0(0 \%)$ & $0(0 \%)$ & $0(0 \%)$ & $1(2 \%)$ & $1(1 \%)$ & $0(0 \%)$ & $0(0 \%)$ & $0(0 \%)$ \\
\hline JEB & $0(0 \%)$ & $2(8 \%)$ & $2(6 \%)$ & $0(0 \%)$ & $6(10 \%)$ & $6(6 \%)$ & $0(0 \%)$ & $1(33 \%)$ & $1(25)$ \\
\hline JMSBK & $0(0 \%)$ & $0(0 \%)$ & $0(0 \%)$ & $1(3 \%)$ & $0(0 \%)$ & $1(1 \% 0$ & $0(0 \%)$ & $0(0 \%)$ & $0(0 \%)$ \\
\hline JSB & $0(0 \%)$ & $0(0 \%)$ & $0(0 \%)$ & $2(5 \%)$ & $0(0 \%)$ & $2(2 \%)$ & $0(0 \%)$ & $0(0 \%)$ & $0(0 \%)$ \\
\hline JIEB & $0(0 \%)$ & $0(0 \%)$ & $0(0 \%)$ & $1(3 \%)$ & $3(5 \%)$ & $4(4 \%)$ & $1(100 \%)$ & $0(0 \%)$ & $1(25 \%)$ \\
\hline JEJAK & $1(8 \%)$ & $0(0 \%)$ & $1(3 \%)$ & $1(3 \%)$ & $0(0 \%)$ & $1(1 \%)$ & $0(0 \%)$ & $0(0 \%)$ & $0(0 \%)$ \\
\hline JEP & $0(0 \%)$ & $0(0 \%)$ & $0(0 \%)$ & $1(3 \%)$ & $0(0 \%)$ & $1(1 \%)$ & $0(0 \%)$ & $0(0 \%)$ & $0(0 \%)$ \\
\hline JEPI & $0(0 \%)$ & $0(0 \%)$ & $0(0 \%)$ & $1(3 \%)$ & $1(2 \%)$ & $2(2 \%)$ & $0(0 \%)$ & $0(0 \%)$ & $0(0 \%)$ \\
\hline KEK & $0(0 \%)$ & $1(4 \%)$ & $1(3 \%)$ & $1(3 \%)$ & $3(5 \%)$ & $4(4 \%)$ & $0(0 \%)$ & $0(0 \%)$ & $0(0 \%)$ \\
\hline TOTAL & 12 & 24 & 36 & $38(28 \%)$ & 59 & $97(70 \%)$ & 1 & 3 & $4(2 \%)$ \\
\hline
\end{tabular}

Jurnal yang paling mendominasi dalam penelitian kualitatif adalah JAMAL dengan persentase $46 \%$. Sementara untuk jurnal lain tak lebih dari 10\%, bahkan terdapat 11 jurnal dari 22 jurnal yang tidak menerbitkan penelitian kualitatif mengenai akuntansi sektor publik. Penelitian kualitatif pada JAMAL mengalami kenaikan, yaitu pada tahun 2010-2014 terdapat 6 penelitian dan pada dekade kedua tahun 2015-2018 terdapat 11 penelitian. Sementara itu, jurnal yang paling mendominasi dalam penelitian kuantitatif adalah JAMAL pula dengan persentase 15\%. Baik kualitatif maupun kuantitatif didominasi oleh JAMAL karena secara keseluruhan penelitian mengenai akuntansi sektor publik paling banyak diterbitkan pada jurnal tersebut.

Setelah JAMAL dengan 15\% yang mendominasi pada penelitian kuantitatif, disusul oleh JAB dan JAI yang masing-masing 13\% dan 9\% yang paling banyak menerbitkan artikel dengan metode penelitian kuantitatif. Sementara untuk jurnal lainnya tidak lebih dari 10\%. Dari 22 jurnal, semuanya menerbitkan dengan metode kuantitatif dengan total 97 artikel. Sebanyak 4 artikel diterbitkan dengan metode campuran pada 22 jurnal terakreditasi mengenai akuntansi sektor publik. Keempat artikel tersebut diterbitkan oleh JAAI dengan 2 artikel, dan JEB dan JIEB dengan masing-masing 1 artikel. 
Keempat artikel dengan metode campuran tersebut diterbitkan dalam dekade kedua yaitu tahun 2015-2018, sementara untuk dekade pertama tidak ada yang menerbitkan dengan metode campuran. Jadi dapat disimpulkan bahwa metode penelitian yang paling banyak digunakan dalam akuntansi sektor publik adalah metode kuantitatif, disusul metode kualitatif dan yang terakhir adalah metode campuran yang mempunyai persentase 3\%. Pada kategori kedua yang dapat dilihat pada tabel 5, metode yang paling mendominasi untuk penelitian akuntansi sektor publik adalah metode archival dan survei yang maasing-masing memperoleh persentase $32 \%$ dan $34 \%$. Kesembilan metode rata-rata mengalami kenaikan dari dekade pertama 2010-2014 ke dekade kedua 2015-2018. Kenaikan yang paling signifikan terlihat pada metode yang sama yaitu metode survei dan archival. Sementara itu, metode yang paling jarang digunakan peneliti pada penelitian sektor publik adalah metode eksperimen dengan persentase $1 \%$ disusul metode kajian pustaka, fenomenologi, dan interpretif.

Tabel 5. Metode Penelitian

\begin{tabular}{lccc}
\hline \multicolumn{1}{c}{ Metode Penelitian } & $\mathbf{2 0 1 0 - 2 0 1 4}$ & $\mathbf{2 0 1 5 - 2 0 1 8}$ & $\mathbf{2 0 1 0 - 2 0 1 8}$ \\
\hline Eksperimen & $0(0 \%)$ & $1(1 \%)$ & $1(1 \%)$ \\
Survei & $20(39 \%)$ & $27(31 \%)$ & $47(34 \%)$ \\
Archival & $13(25 \%)$ & $31(36 \%)$ & $44(32 \%)$ \\
Kajian Pustaka & $0(0 \%)$ & $1(1 \%)$ & $2(1 \%)$ \\
Studi Kasus & $5(20 \%)$ & $7(8 \%)$ & $12(9 \%)$ \\
Deskriptif & $10(19 \%)$ & $10(12 \%)$ & $20(15 \%)$ \\
Interpretif & $2(4 \%)$ & $2(2 \%)$ & $4(3 \%)$ \\
Fenomenologi & $1(2 \%)$ & $2(2 \%)$ & $3(2 \%)$ \\
Lain-Lain & $0(0 \%)$ & $5(2 \%)$ & $5(4 \%)$ \\
\hline Total & $\mathbf{5 1}$ & $\mathbf{8 6}$ & $\mathbf{1 3 7}$
\end{tabular}

Karakteristik jurnal

Tabel 7 mentabulasi topik penelitian akuntansi sektor publik berdasarkan jurnal. Hasil tabulasi data menunjukkan bahwa topik akuntansi keuangan mendominasi pada JAK, JAAI, JAB, JIAB, MRAAI, KEK. Sementara topik audit sektor publik mendominasi JAKI, JAMAL, dan juga JIAB. Topik sistem akuntansi sektor publik rata-rata hanya ada satu penelitian dan 14 jurnal tidak meneliti mengenai topik ini. Sementara untuk topik akuntansi manajemen tidak ada jurnal yang mendominasi namun secara keseluruhan terdapat 16 penelitian pada semua jurnal.

Pada tabel 8 dan 9 terlihat bahwa penelitian kuantitatif hampir mendominasi penelitian bidang akuntansi sektor publik pada 22 jurnal. Metode survei adalah yang paling banyak digunakan dan mendominasi di sebagian besar jurnal terakreditasi. JA, JABM dan JMSBK mempunyai persentase 100\% untuk metode survei, artinya penelitian sektor publik pada ketiga jurnal tersebut dilakukan dengan metode survei. Metode yang mendominasi selanjutnya adalah metode archival dan studi kasus. 
Tabel 6a. Daftar Topik Penelitian Akuntansi Sektor Publik - Sistem Akuntansi

\begin{tabular}{lrrr}
\hline \multicolumn{1}{c}{ Topik } & $\mathbf{2 0 1 0 - 2 0 1 4}$ & $\mathbf{2 0 1 5 - 2 0 1 8}$ & $\mathbf{2 0 1 0 - 2 0 1 8}$ \\
\hline Sistem Pengendalian Internal Pemerintah & $0(0 \%)$ & $2(100 \%)$ & $2(25 \%)$ \\
Implementasi E-Government & $2(33 \%)$ & $0(0 \%)$ & $2(25 \%)$ \\
Implementasi SAKIP & $2(33 \%)$ & $0(0 \%)$ & $2(25 \%)$ \\
Sistem Informasi & $1(17 \%)$ & $0(0 \%)$ & $1(13 \%)$ \\
Niat Pengguanaan Sistem Informasi & & & \\
Keuangan Daerah & $1(17 \%)$ & $0(0 \%)$ & $1(13 \%)$ \\
\hline Jumlah & 6 & 2 & 8 \\
\hline
\end{tabular}

Tabel 6b. Daftar Topik Penelitian Akuntansi Sektor Publik - Akuntansi Keuangan

\begin{tabular}{|c|c|c|c|}
\hline Topik & 2010-2014 & $2015-2018$ & 2010-2018 \\
\hline Akuntabilitas Anggaran & $0(0 \%)$ & $1(2 \%)$ & $1(2 \%)$ \\
\hline Akuntabilitas Kinerja & $2(13 \%)$ & $3(7 \%)$ & $5(8 \%)$ \\
\hline Akuntabilitas Laporan Keuangan & $0(0 \%)$ & $3(7 \%)$ & $3(5 \%)$ \\
\hline Alokasi Belanja Daerah & $0(0 \%)$ & $1(2 \%)$ & $1(2 \%)$ \\
\hline Belanja Hibah & $0(0 \%)$ & $1(2 \%)$ & $1(2 \%)$ \\
\hline Belanja Modal & $2(13 \%)$ & $0(0 \%)$ & $2(3 \%)$ \\
\hline Cash Forecasting & $0(0 \%)$ & $1(2 \%)$ & $1(2 \%)$ \\
\hline Dana Desa & $0(0 \%)$ & $1(2 \%)$ & $1(2 \%)$ \\
\hline Desentralisasi Fiskal & $1(6 \%)$ & $0(0 \%)$ & $1(2 \%)$ \\
\hline Discretionary Fund & $0(0 \%)$ & $1(2 \%)$ & $1(2 \%)$ \\
\hline Flypaper Effect & $2(13 \%)$ & $3(7 \%)$ & $5(8 \%)$ \\
\hline Hutang Pemerintah & $1(6 \%)$ & $0(0 \%)$ & $1(2 \%)$ \\
\hline Implementasi Anggaran Berbasis Kinerja & $1(6 \%)$ & $0(0 \%)$ & $1(2 \%)$ \\
\hline Indeks Pembangunan Manusia & $0(0 \%)$ & $2(5 \%)$ & $2(3 \%)$ \\
\hline Kepuasan Aparatur Pemerintah & $1(6 \%)$ & $0(0 \%)$ & $1(2 \%)$ \\
\hline Ketepatan Waktu Penetapan APBD & $0(0 \%)$ & $1(2 \%)$ & $1(2 \%)$ \\
\hline Ketepatan waktu penyampaian LK & $0(0 \%)$ & $1(2 \%)$ & $1(2 \%)$ \\
\hline Kinerja Fiskal & $1(6 \%)$ & $1(2 \%)$ & $2(3 \%)$ \\
\hline Kinerja Keuangan Pemerintah daerah & $1(6 \%)$ & $3(7 \%)$ & $4(7 \%)$ \\
\hline Kualitas Akuntabilitas & $0(0 \%)$ & $2(5 \%)$ & $2(3 \%)$ \\
\hline Kualitas Anggaran & $0(0 \%)$ & $1(2 \%)$ & $1(2 \%)$ \\
\hline Kualitas APBD & $0(0 \%)$ & $1(2 \%)$ & $1(2 \%)$ \\
\hline Kualitas Laporan Keuangan & $0(0 \%)$ & $1(2 \%)$ & $1(2 \%)$ \\
\hline Partisipasi Anggaran & $1(6 \%)$ & $1(2 \%)$ & $2(3 \%)$ \\
\hline Peerlakuan Aset Tetap & $0(0 \%)$ & $1(2 \%)$ & $1(2 \%)$ \\
\hline Pemahaman Pengelola Keuangan Desa & $0(0 \%)$ & $1(2 \%)$ & $1(2 \%)$ \\
\hline Penerapan Anggaran Responsif Gender & $0(0 \%)$ & $1(2 \%)$ & $1(2 \%)$ \\
\hline Pengadaan Barang dan Jasa & $0(0 \%)$ & $1(2 \%)$ & $1(2 \%)$ \\
\hline Penganggaran & $0(0 \%)$ & $3(7 \%)$ & $3(5 \%)$ \\
\hline Pengungkapan Kebijakan Fiskal & $1(6 \%)$ & $0(0 \%)$ & $1(2 \%)$ \\
\hline Pengungkapan Laporan Keuangan & $1(6 \%)$ & $3(7 \%)$ & $4(7 \%)$ \\
\hline Perencanaan Anggaran & $0(0 \%)$ & $1(2 \%)$ & $1(2 \%)$ \\
\hline
\end{tabular}


RIZKY, HP \& SETIAWAN, D. PERKEMBANGAN PENELITIAN AKUNTANSI ...

\begin{tabular}{lrrr}
\hline \multicolumn{1}{c}{ Topik } & $\mathbf{2 0 1 0 - 2 0 1 4}$ & $\mathbf{2 0 1 5 - 2 0 1 8}$ & $\mathbf{2 0 1 0 - 2 0 1 8}$ \\
\hline Perubahan APBD & $0(0 \%)$ & $1(2 \%)$ & $1(2 \%)$ \\
Praktik Internet Financial Reporting (IFR) & $0(0 \%)$ & $1(2 \%)$ & $1(2 \%)$ \\
Saldo Kas & $0(0 \%)$ & $1(2 \%)$ & $1(2 \%)$ \\
\hline Jumlah & 16 & 43 & 58 \\
\hline
\end{tabular}

Tabel 6c. Daftar Topik Penelitian Akuntansi Sektor Publik - Akuntansi Manajemen

\begin{tabular}{lrrr}
\hline \multicolumn{1}{c}{ Topik } & $\mathbf{2 0 1 0 - 2 0 1 4}$ & $\mathbf{2 0 1 5 - 2 0 1 8}$ & $\mathbf{2 0 1 0 - 2 0 1 8}$ \\
\hline Kinerja Aparatur Pemerintah Daerah & $5(56 \%)$ & $5(63 \%)$ & $10(59 \%)$ \\
Balancescorecard & $2(22 \%)$ & $0(0 \%)$ & $2(12 \%)$ \\
Performance Measurement Systems & $1(11 \%)$ & $1(13 \%)$ & $2(12 \%)$ \\
Penganggaran Berbasis Kinerja & $0(0 \%)$ & $1(13 \%)$ & $1(6 \%)$ \\
Penerapan Just in Time & $0(0 \%)$ & $1(13 \%)$ & $1(6 \%)$ \\
Pengukuran Kinerja & $1(11 \%)$ & $0(0 \%)$ & $1(6 \%)$ \\
\hline Jumlah & 9 & 8 & 17 \\
\hline
\end{tabular}

Tabel 6d. Daftar Topik Penelitian Akuntansi Sektor Publik - Regulasi

\begin{tabular}{lrrr}
\multicolumn{1}{c}{ Topik } & $\mathbf{2 0 1 0 - 2 0 1 4}$ & $\mathbf{2 0 1 5 - 2 0 1 8}$ & $\mathbf{2 0 1 0 - 2 0 1 8}$ \\
\hline Implementasi PP No.71 Tahun 2010 & $3(100 \%)$ & $8(89 \%)$ & $11(92 \%)$ \\
SAP 24 & $0(0 \%)$ & $1(11 \%)$ & $1(8 \%)$ \\
\hline Jumlah & 3 & 9 & 12 \\
\hline
\end{tabular}

Tabel 6e. Daftar Topik Penelitian Akuntansi Sektor Publik - Audit

\begin{tabular}{lrrr}
\hline \multicolumn{1}{c}{ Topik } & $\mathbf{2 0 1 0 - 2 0 1 4}$ & $\mathbf{2 0 1 5 - 2 0 1 8}$ & $\mathbf{2 0 1 0 - 2 0 1 8}$ \\
\hline Kualitas Audit & $1(13 \%)$ & $5(33 \%)$ & $6(26 \%)$ \\
Opini Audit & $3(38 \%)$ & $2(13 \%)$ & $5(22 \%)$ \\
Kinerja Audit & $1(13 \%)$ & $0(0 \%)$ & $1(4 \%)$ \\
Peran Audit dalam Pemberantasan Korupsi & $1(13 \%)$ & $0(0 \%)$ & $1(4 \%)$ \\
Audit & $1(13 \%)$ & $0(0 \%)$ & $1(4 \%)$ \\
Fraud & $1(13 \%)$ & $4(27 \%)$ & $5(22 \%)$ \\
Determinan Tingkat Penyimpangan Bantuan & & & \\
Sosial & $0(0 \%)$ & $1(7 \%)$ & $1(4 \%)$ \\
Pelaporan Pelanggaran & $0(0 \%)$ & $1(7 \%)$ & $1(4 \%)$ \\
Mendeteksi Kecurangan & $0(0 \%)$ & $1(7 \%)$ & $1(4 \%)$ \\
Konflik Peran pada Auditor Internal & $0(0 \%)$ & $1(7 \%)$ & $1(4 \%)$ \\
\hline Jumlah & 8 & 15 & 22 \\
\hline
\end{tabular}

Tabel 6f. Daftar Topik Penelitian Akuntansi Sektor Publik - Pajak

\begin{tabular}{lrrr}
\hline \multicolumn{1}{c}{ Topik } & 2010-2014 & 2015-2018 & 2010-2018 \\
\hline Pemotongan dan Pemungutan Pajak & $2(40 \%)$ & $0(0 \%)$ & $2(29 \%)$ \\
Amnesti Pajak & $0(0 \%)$ & $1(50 \%)$ & $1(14 \%)$ \\
Dampak PP terhadap Penerimaan Pajak & $0(0 \%)$ & $1(50 \%)$ & $1(14 \%)$ \\
Pajak Bumi dan Bangunan & $1(20 \%)$ & $0(0 \%)$ & $1(14 \%)$ \\
Pajak Penghasilan & $0(0 \%)$ & $0(0 \%)$ & $0(0 \%)$
\end{tabular}




\begin{tabular}{lrrr}
\hline \multicolumn{1}{c}{ Topik } & 2010-2014 & 2015-2018 & \multicolumn{1}{c}{ 2010-2018 } \\
\hline Sunset Policy & $1(20 \%)$ & $0(0 \%)$ & $1(14 \%)$ \\
Penerimaan PPH dan PPN & $1(20 \%)$ & $0(0 \%)$ & $1(14 \%)$ \\
\hline Jumlah & 5 & 2 & 7 \\
\hline
\end{tabular}

Tabel 6g. Daftar Topik Penelitian Akuntansi Sektor Publik - Lain-lain

\begin{tabular}{lrrr}
\hline \multicolumn{1}{c}{ Topik } & $\mathbf{2 0 1 0 - 2 0 1 4}$ & $\mathbf{2 0 1 5 - 2 0 1 8}$ & $\mathbf{2 0 1 0 - 2 0 1 8}$ \\
\hline Sikap dan Perilaku Penyusunan KUA dan PPAS & $1(17 \%)$ & $0(0 \%)$ & $1(8 \%)$ \\
Pertumbuhan Ekonomi & $0(0 \%)$ & $1(17 \%)$ & $1(8 \%)$ \\
Pengembangan Karir dan Kepuasan Kerja & $1(17 \%)$ & $0(0 \%)$ & $1(8 \%)$ \\
Komitmen Organisasional & $1(17 \%)$ & $0(0 \%)$ & $1(8 \%)$ \\
Identifikasi Faktor Keperilakuan pada Proses & & & \\
Penganggaran & $1(17 \%)$ & $0(0 \%)$ & $1(8 \%)$ \\
Optimalisasi Penggunaan Aset & $0(0 \%)$ & $1(17 \%)$ & $1(8 \%)$ \\
Kinerja dan Keterikatan Kerja & $0(0 \%)$ & $1(17 \%)$ & $1(8 \%)$ \\
Efektivitas, efisiensi dan taggung jawab sumber & & & \\
daya manusia & $1(17 \%)$ & $0(0 \%)$ & $1(8 \%)$ \\
Analisis Konvergensi dan Pertumpuhan PDRB & & & \\
setelah Otonomi Daerah & $1(17 \%)$ & $0(0 \%)$ & $1(8 \%)$ \\
Pengambilan Keputusan Pemerintah Daerah & $0(0 \%)$ & $1(17 \%)$ & $1(8 \%)$ \\
Produk Domestik Regional Bruto & $0(0 \%)$ & $1(17 \%)$ & $1(8 \%)$ \\
Penatausahaan Aset Tetap & $0(0 \%)$ & $1(17 \%)$ & $1(8 \%)$ \\
\hline Jumlah & 6 & 6 & 12 \\
\hline
\end{tabular}

Tabel 7. Karakteristik Jurnal berdasarkan Topik

\begin{tabular}{|c|c|c|c|c|c|c|c|c|}
\hline Jurnal & $\begin{array}{l}\text { Sis - } \\
\text { Akt }\end{array}$ & $\begin{array}{l}\text { Akt - } \\
\text { Keu }\end{array}$ & $\begin{array}{l}\text { Akt - } \\
\text { Mnj }\end{array}$ & $\begin{array}{c}\text { Regu- } \\
\text { lasi }\end{array}$ & Audit & Pajak & $\begin{array}{l}\text { Lain- } \\
\text { Lain }\end{array}$ & Jumlah \\
\hline JAK & $1(17 \%)$ & $2(33 \%)$ & $0(0 \%)$ & $3(50 \%)$ & $0(0 \%)$ & $0(0 \%)$ & $0(0 \%)$ & 6 \\
\hline JAAI & $1(8 \%)$ & $7(58 \%)$ & $2(17 \%)$ & $1(8 \%)$ & $1(8 \%)$ & I & $0(0 \%)$ & 12 \\
\hline JAB & $1(7 \%)$ & $7(50 \%)$ & $0(0 \%)$ & $1(7 \%)$ & $5(36 \%)$ & $0(0 \%)$ & $0(0 \%)$ & 14 \\
\hline JAI & $0(0 \%)$ & $6(60 \%)$ & $0(0 \%)$ & $2(20 \%)$ & $2(20 \%)$ & $0(0 \%)$ & $0(0 \%)$ & 10 \\
\hline JAKI & $1(20 \%)$ & $2(40 \%$ & $0(0 \%)$ & $0(0 \%)$ & $2(40 \%)$ & $0(0 \%)$ & $0(0 \%)$ & 5 \\
\hline JAMAL & $2(6 \%)$ & $7(22 \%)$ & $6(19 \%)$ & $3(9 \%)$ & $7(22 \%)$ & $3(9 \%)$ & $4(13 \%)$ & 32 \\
\hline JDA & $0(0 \%)$ & $3(33 \%)$ & $3(33 \%)$ & $1(11 \%)$ & $1(11 \%)$ & $1(11 \%)$ & $0(0 \%)$ & 9 \\
\hline JIAB & $1(17 \%)$ & $2(33 \%)$ & $1(17 \%)$ & $0(0 \%)$ & $1(17 \%)$ & $1(17 \%)$ & $0(0 \%)$ & 6 \\
\hline RAKI & $0(0 \%)$ & $3(100 \%)$ & $0(0 \%)$ & $0(0 \%)$ & $0(0 \%)$ & $0(0 \%)$ & $0(0 \%)$ & 3 \\
\hline MRAAI & $0(0 \%)$ & $1(100 \%)$ & $0(0 \%)$ & $0(0 \%)$ & $0(0 \%)$ & $0(0 \%)$ & $0(0 \%)$ & 1 \\
\hline JA & $0(0 \%)$ & $0(0 \%)$ & $1(50 \%)$ & $0(0 \%)$ & $0(0 \%)$ & $0(0 \%)$ & $1(50 \%)$ & 2 \\
\hline ASSETS & $1(14 \%)$ & $3(43 \%)$ & $2(29 \%)$ & $0(0 \%)$ & $0(0 \%)$ & $0(0 \%)$ & $1(14 \%)$ & 7 \\
\hline IJKEB & $0(0 \%)$ & $1(50 \%)$ & $0(0 \%)$ & $0(0 \%)$ & $0(0 \%)$ & $0(0 \%)$ & $1(50 \%)$ & 2 \\
\hline JABM & $0(0 \%)$ & $1(100 \%)$ & $0(0 \%)$ & $0(0 \%)$ & $0(0 \%)$ & $0(0 \%)$ & $0(0 \%)$ & 1 \\
\hline JEB & $0(0 \%)$ & $6(67 \%)$ & $0(0 \%)$ & $1(11 \%)$ & $2(22 \%)$ & $0(0 \%)$ & $0(0 \%)$ & 9 \\
\hline JMSBK & $0(0 \%)$ & $0(0 \%)$ & $0(0 \%)$ & $0(0 \%)$ & $0(0 \%)$ & $0(0 \%)$ & $1(100 \%)$ & 1 \\
\hline JSB & $0(0 \%)$ & $0(0 \%)$ & $0(0 \%)$ & $0(0 \%)$ & $1(50 \%)$ & $0(0 \%)$ & $1(50 \%)$ & 2 \\
\hline JIEB & $0(0 \%)$ & $2(40 \%)$ & $1(20 \%)$ & $0(0 \%)$ & $1(20 \%)$ & $0(0 \%)$ & $1(20 \%)$ & 5 \\
\hline
\end{tabular}


RIZKY, HP \& SETIAWAN, D. PERKEMBANGAN PENELITIAN AKUNTANSI ...

\begin{tabular}{lcrcrrrrr}
\hline Jurnal & $\begin{array}{c}\text { Sis - } \\
\text { Akt }\end{array}$ & $\begin{array}{c}\text { Akt - } \\
\text { Keu }\end{array}$ & $\begin{array}{c}\text { Akt - } \\
\text { Mnj }\end{array}$ & $\begin{array}{c}\text { Regu- } \\
\text { lasi }\end{array}$ & Audit & Pajak & $\begin{array}{c}\text { Lain- } \\
\text { Lain }\end{array}$ & Jumlah \\
\hline JEJAK & $0(0 \%)$ & $0(0 \%)$ & $0(0 \%)$ & $0(0 \%)$ & $0(0 \%)$ & $0(0 \%)$ & $2(100 \%)$ & $\mathbf{2}$ \\
JEP & $0(0 \%)$ & $1(100 \%)$ & $0(0 \%)$ & $0(0 \%)$ & $0(0 \%)$ & $0(0 \%)$ & $0(0 \%)$ & $\mathbf{1}$ \\
JEPI & $0(0 \%)$ & $1(50 \%)$ & $0(0 \%)$ & $0(0 \%)$ & $0(0 \%)$ & $1(50 \%)$ & $0(0 \%)$ & $\mathbf{2}$ \\
KEK & $0(0 \%)$ & $4(80 \%)$ & $0(0 \%)$ & $0(0 \%)$ & $0(0 \%)$ & $1(20 \%)$ & $0(0 \%)$ & $\mathbf{5}$ \\
JUMLAH & $\mathbf{8}$ & $\mathbf{5 8}$ & $\mathbf{1 7}$ & $\mathbf{1 2}$ & $\mathbf{2 2}$ & $\mathbf{7}$ & $\mathbf{1 2}$ & $\mathbf{1 3 7}$ \\
\hline
\end{tabular}

Tabel 8. Karakteristik Jurnal Berdasarkan Metode Penelitian

\begin{tabular}{|c|c|c|c|c|c|c|c|c|c|}
\hline Jurnal & $\begin{array}{c}\text { Eksperi } \\
\text { men }\end{array}$ & Survei & $\begin{array}{c}\text { Archi- } \\
\text { val }\end{array}$ & $\begin{array}{c}\text { Kajian } \\
\text { Pustaka }\end{array}$ & $\begin{array}{c}\text { Studi } \\
\text { Kasus } \\
\end{array}$ & $\begin{array}{c}\text { Deskrip- } \\
\text { tif }\end{array}$ & $\begin{array}{l}\text { Inter- } \\
\text { pretif }\end{array}$ & $\begin{array}{c}\text { Fenome } \\
\text { nologi }\end{array}$ & $\begin{array}{l}\text { Lain- } \\
\text { Lain }\end{array}$ \\
\hline JAK & $0(0 \%)$ & $2(33 \%)$ & $1(17 \%)$ & $0(0 \%)$ & $1(17 \%)$ & $1(17 \%)$ & $1(17 \%)$ & & $0(0 \%)$ \\
\hline JAAI & & 5 & 3 & & & & & & \\
\hline JAB & & $4(31$ & $9(69 \%)$ & & & & & & \\
\hline JAI & & $7(64$ & $2(18 \%)$ & & $2(1$ & & & & $0(0 \%)$ \\
\hline JAKI & $0(0 \%)$ & $2(40 \%)$ & $3(60 \%)$ & & $0(0 \%)$ & $0(0 \%)$ & & & $0(C$ \\
\hline JAMA & $\%)$ & $7(22$ & $7(22 \%)$ & & $5(1$ & $7(22 \%)$ & & & 2 \\
\hline JDA & $0(0 \%)$ & $4(44 \%)$ & $1(11 \%)$ & & $1(1$ & (33\%) & & & $0(0 \%)$ \\
\hline JIAB & & $1(17$ & $1(17$ & & & & & & \\
\hline RAKI & $0(0 \%)$ & $1(33 \%)$ & $2(67 \%)$ & & & $0(C$ & & & 0( \\
\hline MRA & $\%)$ & $0(0 \%)$ & $0(0 \%)$ & & & & & & $\%)$ \\
\hline JA & $0(0 \%)$ & $2(10$ & $0(0 \%)$ & & & & & & \\
\hline ASSE & 0( & $3(43$ & $3(43 \%)$ & & & $1(14 \%)$ & & & \\
\hline IJKEB & $0(0 \%)$ & $1(50 \%)$ & $1(50 \%)$ & & 0( & $0(0 \%)$ & & & \\
\hline JABM & $0(0$ & $1(10$ & $0(0 \%)$ & & & & & & \\
\hline JEB & $0(0 \%)$ & $2(22 \%)$ & $4(44 \%)$ & $0(C$ & 2( & $0(0 \%)$ & \%) & & $1(11 \%)$ \\
\hline JMSE & & $1(10$ & 0 & & & & & & \\
\hline JSB & 0 & $1(50$ & $1(50 \%)$ & & & 6) & & & \\
\hline JIEB & & $3(6$ & & & & & & & \\
\hline JEJAK & & & & & & & & & \\
\hline JEP & $0(0 \%)$ & $0(0 \%)$ & $1(100 \%)$ & $0(0 \%)$ & $0(0 \%)$ & $0(0 \%)$ & $0(0 \%)$ & $0(0 \%)$ & $0(0 \%)$ \\
\hline JEPI & 0 & $0(0$ & $2(100 \%)$ & & & & & & \\
\hline KEK & $0(0 \%)$ & $0(0 \%)$ & $1(20 \%)$ & $0(0 \%)$ & $0(0 \%)$ & $3(60 \%)$ & $0(0 \%)$ & $0(0 \%)$ & $1(20 \%)$ \\
\hline
\end{tabular}

\section{Karakteristik Artikel}

Tabel 9 menunjukkan tabulasi silang antara Metode Penelitian kualitatif, kuantitatif, dan campuran dengan topik penelitian. Tabel tersebut menunjukkan bahwa penelitian dengan metode kuantitatif mendominasi semua topik penelitian. Dari ketujuh topik penelitian, metode kuantitatif paling banyak digunakan pada topik akuntansi keuangan sebesar $46 \%$. Setelahnya disusul oleh topik audit $18 \%$ dan topik akuntansi manajemen $11 \%$. Sementara itu, untuk metode kualitatif terbanyak dengan topik akuntansi keuangan sebesar 35\% dan regulasi dengan 19\%. Metode campuran paling sedikit digunakan yaitu pada topik akuntansi keuangan dan akuntansi manajemen dengan presnetase masing-masing sebesar $50 \%$.

Tabel 10 menunjukkkan bahwa topik akuntansi keuangan didominasi oleh metode archival dengan 29 penelitian disusul dengan metode survei dengan 13 penelitian. Akuntansi manajemen, audit, dan regulasi didominasi oleh metode survei. 
Topik penelitian pajak didominasi oleh archival. Sementara itu, topik sistem akuntansi metode survei dan studi kasus dan archival paling banyak digunakan. Untuk metode lainnya didominasi oleh metode survei. Secara keseluruhan metode yang paling banyak digunakan adalah metode survei dan archival yaitu sebanyak masing-masing 47 dan 44 penelitian.

Tabel 9. Tabulasi Data Metode Penelitian Jurnal dan Topik Penelitian

\begin{tabular}{lrrrr}
\hline \multirow{2}{*}{ Topik Penelitian } & \multicolumn{3}{c}{ Metode Penelitian } & \multirow{2}{*}{ Kumlah } \\
\cline { 2 - 4 } Sistem Akuntansi & $2(6 \%)$ & $6(6 \%)$ & $0(0 \%)$ & 8 \\
Akuntansi Keuangan & $13(33 \%)$ & $45(46 \%)$ & $2(50 \%)$ & 60 \\
Akuntansi Manajemen & $3(8 \%)$ & $11(11 \%)$ & $2(50 \%)$ & 16 \\
Regulasi & $7(19 \%)$ & $5(5 \%)$ & $0(0 \%)$ & 12 \\
Audit & $6(17 \%)$ & $17(18 \%)$ & $0(0 \%)$ & 22 \\
Pajak & $3(8 \%)$ & $4(4 \%)$ & $0(0 \%)$ & 7 \\
Lain-Lain & $3(8 \%)$ & $9(9 \%)$ & $0(0 \%)$ & 12 \\
\hline JUMLAH & 37 & 97 & 4 & 137 \\
\hline
\end{tabular}

Tabel 10. Tabulasi Data Metode Penelitian dan Topik Penelitian

\begin{tabular}{|c|c|c|c|c|c|c|c|c|}
\hline \multirow[b]{2}{*}{$\begin{array}{c}\text { Metode } \\
\text { Penelitian }\end{array}$} & \multicolumn{7}{|c|}{ Topik Penelitian } & \multirow[b]{2}{*}{$\begin{array}{l}\text { Jum- } \\
\text { lah }\end{array}$} \\
\hline & $\begin{array}{l}\text { Sis - } \\
\text { Akt }\end{array}$ & $\begin{array}{l}\text { Akt - } \\
\text { Keu }\end{array}$ & $\begin{array}{c}\text { Akt - } \\
\text { Mnj }\end{array}$ & Reg & Audit & Pajak & $\begin{array}{l}\text { Lain- } \\
\text { Lain }\end{array}$ & \\
\hline Eksperimen & $0(0 \%)$ & $0(0 \%)$ & $0(0 \%)$ & $0(0 \%)$ & $0(0 \%)$ & $0(0 \%)$ & $1(100 \%)$ & 1 \\
\hline Survei & $3(6 \%)$ & $13(28 \%)$ & $7(15 \%)$ & $5(11 \%)$ & $13(28 \%)$ & $1(2 \%)$ & $5(11 \%)$ & 47 \\
\hline $\begin{array}{l}\text { Archival } \\
\text { Kajian }\end{array}$ & $2(5 \%)$ & $29(66 \%)$ & $4(9 \%)$ & $0(0 \%)$ & $5(11 \%)$ & $1(2 \%)$ & $3(7 \%)$ & 44 \\
\hline Pustaka & $\begin{array}{l}0(0 \%) \\
2(17 \%\end{array}$ & $1(100 \%)$ & $0(0 \%)$ & $0(0 \%)$ & $0(0 \%)$ & $0(0 \%)$ & $0(0 \%)$ & 2 \\
\hline Studi Kasus & ) & $3(25 \%)$ & $2(17 \%)$ & $3(25 \%)$ & $2(17 \%)$ & $0(0 \%)$ & $0(0 \%)$ & 12 \\
\hline Deskriptif & $1(5 \%)$ & $8(40 \%)$ & $2(10 \%)$ & $3(15 \%)$ & $2(10 \%)$ & $3(15 \%)$ & $1(5 \%)$ & 20 \\
\hline $\begin{array}{l}\text { Interpretif } \\
\text { Fenomenolo }\end{array}$ & $0(0 \%)$ & $1(25 \%)$ & $0(0 \%)$ & $1(25 \%)$ & $1(25 \%)$ & $0(0 \%)$ & $1(25 \%)$ & 4 \\
\hline gi & $0(0 \%)$ & $1(33 \%)$ & $1(33 \%)$ & $0(0 \%)$ & $0(0 \%)$ & $1(33 \%)$ & $0(0 \%)$ & 3 \\
\hline Lain-Lain & $0(0 \%)$ & $3(60 \%)$ & $0(0 \%)$ & $0(0 \%)$ & $0(0 \%)$ & $1(20 \%)$ & $1(20 \%)$ & 5 \\
\hline JUMLAH & 8 & 60 & 16 & 12 & 22 & 7 & 12 & 137 \\
\hline
\end{tabular}

\section{SIMPULAN}

Dari tabel-tabel yang telah ditampilkan pada pembahasan, diketahui bahwa masih banyak topik dalam akuntansi sektor publik yang masih jarang diteliti, padahal topik tersebut dapat menjadi hal yang menarik. Penelitian selanjutnya mengenai akuntansi sektor publik diharapkan dapat menggunakan artikel ini untuk melihat topik penelitian yang masih jarang diteliti misalnya mengenai pengelolaan keuangan pada Badan Usaha Milik Desa (BUMDes) serta bagaimana perkembangan BUMDes dari sisi akuntansi sektor publik.

Dari ketujuh kategori topik sektor publik pada penelitian ini selama 9 tahun terakhir, penelitian mengenai perpajakan menjadi topik paling sedikit yang telah 
diteliti. Hal ini dapat menjadi peluang bagi peneliti, misalnya mengenai sunset policy. Selain itu topik mengenai sistem akuntansi juga dapat menjadi peluang penelitian mengingat sistem akuntansi merupakan suatu hal penting dalam pelaporan keuangan dalam sektor publik maupun swasta. Selain itu penelitiaan selanjutnya dapat mengambil topik mengenai revolusi 4.0 karena topik tersebut adalah topik yang sedang banyak dibicarakan. Topik tersebut dapat mengambil masalah mengenai apakah revolusi 4.0 dapat memengaruhi pelayanan pada pemerintah mengingat tujuan utama dari pemerintah adalah melayani masyarakat. Lalu sistem akuntansi seperti apa yang akan diterapkan apabila dikaitkan dengan revolusi 4.0 tersebut.

Pada penelitian ini, peneliti menganalisis 137 artikel yang membahas mengenai akuntansi sektor publik dan diterbitkan pada 22 jurnal terakreditasi di Indonesia dan diklasifikasikan berdasarkan topik dan metode selama 9 tahun mulai tahun 2010-2018. Mayoritas penelitian mengenai akuntansi sektor publik ini diterbitkan di Jurnal Akuntansi Multiparadigma (JAMAL), Jurnal Akuntansi dan Auditing Indonesia (JAAI), Jurnal Akuntansi dan Bisnis (JAB), dan Jurnal Akuntansi dan Investasi (JAI). Topik yang paling banyak dibahas pada penelitian akuntansi sektor publik pada 22 jurnal terakreditasi adalah topik mengenai akuntansi keuangan yaitu pengungkapan laporan keuangan, akuntabilitas kinerja, dan flypaper effect. Sementara itu topik yang masih jarang diteliti adalah sistem akuntansi sektor publik dan perpajakan.

Pada 22 jurnal yang diteliti selama tahun 2010-2018 metode penelitian yang paling sering digunakan adalah kuantitatif dengan persentase $70 \%$ sementara metode kualitatif sebesar 28\%. Metode yang paling sering digunakan adalah survei dan archival yang mempunyai persentase masing-masing 34\% dan $32 \%$. Pada penelitian ini diketahui bahwa eksperimen masih sangat jarang digunakan oleh peneliti, oleh karena itu ini hal ini dapat menjadi peluang bagi penelitian selanjutnya untuk menggunakan metode eksperimen.

\section{DAFTAR PUSTAKA}

Abdullah, S., \& Muthia, N. (2017). Determinan Saldo Kas Akhir Tahun pada Pemerintah Daerah di Aceh. Jurnal Akuntansi Dan Auditing Indonesia, 21(2).

Afdalia, N., Pontoh, G. T., \& Kartini. (2014). Theory of Planned Behavior dan Readiness for Change dalam Memprediksi Niat Implementasi Peraturan Pemerintah Nomor 71 Tahun 2010. Jurnal Akuntansi Dan Auditing Indonesia, 18(2110-122).

Ahyaruddin, M., \& Akbar, R. (2017). Akuntabilitas dan kinerja instansi pemerintah: Semu atau nyata ? Jurnal Akuntansi Dan Auditing Indonesia, 21(2).

Alhajjriana, G. I., Nor, W., \& Wijaya, R. (2017). Faktor-Faktor yang Mempengaruhi Internet Financial Reporting Pemerintah daerah dan Implikasinya terhadap Akuntabilitas Laporan Keuangan Daerah. Jurnal Akuntansi Dan Bisnis, 17(2), 100109.

Amalia, W. R., Nor, W., \& Nordiansyah, M. (2015). Flypaper Effect pada Pendapatan Asli Daerah (PAD), Dana Alokasi Umum (DAU), dan Dana Alokasi Khusus (DAK) terhadap Belanja Daerah pada Pemerintah Kabupaten/Kota di provinsi Kalimantan Selatan (2009-2013). Jurnal Akuntansi Dan Bisnis, 15(1), 1-12.

Ambaarwati, A., \& Payamta. (2015). Pengaruh Pendapatan Asli Daerah, Investasi Pemerintah dan Angkatan Kerja terhadap Produk Domestik Regional Bruto Kabupaten/Kota Di Jawa. Jurnal Akuntansi Dan Pendidikan, 4(1), 37-52.

Andhayani, A. (2017). Dilema akrualisasi akuntansi dalam pengelolaan keuangan daerah. Jurnal Akuntansi Multiparadigma, 8(48), 291-307. 
Andika, R., Rahman, T., Irianto, G., \& Rosidi. (2012). Evaluation of E-Budgeting Implementation in Provincial Government of DKI Jakarta Using CIPP Model Approach. Jurnal Akuntansi Dan Investasi, (3), 94-114. https://doi.org/10.18196/jai.2001110

Anggraini, I., \& Setiawan, A. R. (2011). Pengaruh Komitmen Organisasi dan Gaya Kepemimpinan terhadap Hubungan Partisipasi Anggaran dan Kinerja Aparat Pemerintah Daerah. Jurnal Akuntansi Multiparadigma, 2(2), 186-368.

Anggraini, Z. T., \& Nuraina, E. (2014). Nerapan Balanced Scorecard sebagai Alat Ukur Kinerja pada Rumah Sakit Umum daerah Dr. Harjono Ponorogo. Jurnal Akuntansi Dan Pendidikan, 3(2), 75-85.

Arifin, J. F., \& Pratolo, S. (2012). Pengaruh kualitas sistem informasi keuangan daerah terhadap kepuasan aparatur pemerintah daerah menggunakan model delone dan mclean. Jurnal Akuntansi Dan Investasi, 13(1), 28-34.

Arifin, J., Tower, G., \& Porter, S. (2010). Fiskal Policy Disclosure in Indonesian Local Governments. Jurnal Akuntansi Dan Auditing Indonesia, (2005), 13-30.

Aryawati, N. P. A., \& Sudana, I. P. (2018). Kinerja Keuangan Memediasi Dana Perimbangan, Alokasi Belanja Daerah pada Indeks Pembangunan Manusia dan Pertumbuhan Ekonomi. Jurnal Ilmiah Akuntansi Dan Bisnis, 13(1), 28-41.

Aziz, A., Setiawan, H., \& Damayanty, S. A. (2013). Analisis Potensi Penerimaan PPh dan PPn pada Pelaksanaan Program KUR. Kajian Ekonomi Dan Keuangan, 17(2), 159-178.

Azwar. (2016). Peran Alokatif Pemerintah melalui Pengadaan Barang/Jasa dan Pengaruhnya terhadap Perekonomian Indonesia. Kajian Ekonomi Dan Keuangan, 20(2).

Badruzaman, J., \& Chairunnisa, I. (2011). Pengaruh Implementasi Sistem Akuntabilitas Kinerja Instansi Pemerintah (SAKIP) terhadap Penerapan Good Governance. Jurnal Ilmiah Akuntansi Dan Bisnis, (1), 1-22.

Bawono, I. R., \& Halim, A. (2015). Information and nowledge of Public Sector Decision Makers: Experimental Research in the Context of a Local Government Hospital in Indonesia. Journal of Indonesian Economy and Business, 30(2), 113-119.

Biswan, A. T., \& Wardani, F. (2017). Implementasi Just in Time Layanan Penerbitan Nomor Pokok Wajib Pajak. Jurnal Akuntansi Multiparadigma, 8(2), 353-369.

Budiartha, K. (2010). Menelusuri Opini Auditor Independen atas LKPD Pemerintah Provinsi Bali Ketut Budiartha. Jurnal Ilmiah Akuntansi Dan Bisnis.

Butar, S. G. A. B., \& Perdana, H. D. (2017). Penerapan Skeptisme Profesional Auditor Internal Pemerintah dalam Mendeteksi Kecurangan. Jurnal Ekonomi Dan Bisnis, 20(1), 169-188.

Darmayasa, I. N. (2017). Yadnya Sebagai pemaknaan lain atas nilai wajar harta amnesti pajak. Jurnal Akuntansi Multiparadigma, 8(1), 166-182.

Dewi, A. C., Fitriana, A., \& Setiawan, D. (2018). Perkembangan penelitian di bidang pengungkapan di Indonesia: Telaah konseptual Pendahuluan Metode, 22(1), 119. https://doi.org/10.20885/jsb.vol22.iss1.art1

Diptyana, P., \& Rokhmania, N. (2018). Exploring Government Internet Financial Reporting In Indonesia. Jurnal Ekonomi Dan Bisnis, 21(1), 115-137.

Djamhuri, A., \& Rosidi. (2017). Kapabilitas Dinamis , Implementasi Sistem Akuntansi Pemerintahan dan Kualitas Laporan Keuangan SKPD ( Studi pada Pemerintah Kabupaten Kediri ). Jurnal Akuntansi Dan Keuangan, 19(2), 82-101. https://doi.org/10.9744/jak.19.2.82-101

Erawati, T., \& Kurniawan, D. (2018). Penerapan Sistem Akuntansi Berbasis Akrual : Kajian dari Aspek Keperilakuan. Jurnal Ekonomi Dan Bisnis, 21(2), 313-331. 
Ferdiansyah, R. (2016). Analisis Faktor-Faktor yang Mempengaruhi Kualitas Hasil Pemeriksaan Audit Pemerintah (Studi Empiris pada BPKP Perwakilan Provinsi DKI Jakarta). Jurnal Akuntansi Dan Bisnis, 16(2), 109-121.

Firdaus, D., Sayogo, D. S., \& Latifah, S. W. (2010). Evaluasi Penerapan Pp No 71 / 2010 Tentang Standar Akuntansi Pemerintahan Berbasis Akrual : Studi Kasus di Pemda Nganjuk. Jurnal Akuntansi Dan Investasi, (71).

Firhana, M. L. W., \& Santoso, B. (2012). Anteseden dan Impak Komitmen Organisasional pada Organisasi Publik. Jurnal Siasat Bisnis, 16(1), 71-86.

Fitri, F. A., \& Indriani, M. (2011). Perencanaan dan Penganggaran Pemerintah Daerah Otonomi Khusus Ditinjau dari aspek Keperilakuan. Jurnal Akuntansi Multiparadigma, 2(1), 1-185.

Fitri, S. M., Ludigdo, U., \& Djamhuri, A. (2013). Pengaruh Gaya Kepemimpinan, Komitmen, Organisasi, Kualitas Sumber Daya, Reward, dan Punishment terhadap Anggaran Berbasis Kinerja (Studi Empirik pada Pemerintah Kabupaten Lombok Barat). Jurnal Dinamika Akuntansi, 5(2), 157-171.

Gamar, N., \& Djamhuri, A. (2015). Auditor Internal sebagai "Dokter" Fraud di Pemerintah Daerah. Jurnal Akuntansi Multiparadigma, 6(1), 107-122. https://doi.org/10.18202/jamal.2015.04.6009

Gunawan, M. H., \& Nurulita, S. (2017). Government Regulation 46/2013 as Income Tax Income Facility. Jurnal Akuntansi Multiparadigma, (1), 600-611.

Hadi, I., \& Handajani, L. (2017). Determinan Kualitas Hasil Pemeriksaan Auditor Internal Pemerintah Daerah. Jurnal Akuntansi Dan Investasi, 18(2), 183-197. https://doi.org/10.18196/jai.180282

Harumiati, Y., \& Payamta. (2014). Pengaruh Karakteristik Pemerintah Daerah dan Temuann Audit BPK terhadpa Kinerja Pemerintah Daerah Kabupaten/Kota di Indonesia Tahun Anggaran 2011. Jurnal Akuntansi Dan Pendidikan, 3(2), 75-87.

Hasiara, L. O. (2012). Sikap dan Perilaku Pejabat, Unit SKPD dalam Pengelolaan APBD dan Aset Daerah. Jurnal Akuntansi Multiparadigma, 3(1).

Hasniasari, R., \& Sholihin, M. (2014). Analisis Hubungan Penganggaran Partisipatif dan Kinerja : Pengujian Efek Mediasi Keadilan Persepsian dan Komitmen pada Lembaga Hukum Sektor Publik di Indonesia. Jurnal Akuntansi Dan Keuangan, 16(1), 22-32. https://doi.org/10.9744/jak.16.1.22-32

Hasthoro, H. A., \& Sunardi. (2016). Tata Kelola Publik dan Kinerja Keuangan Pemerintah Daerah di Indonesia. Jurnal Ekonomi Dan Bisnis, 19(1), 53-67.

Herawati, N., \& Bandi. (2017). Perpajakan dalam Akuntansi: Suatu Studi Bibliografi. Simposium Nasional Akuntansi XX, (37).

Herwiyanti, E., Sukirman, \& Aziz, F. S. (2017). Analisis Implementasi Akuntansi Berbasis Akrual pada Inspektorat Jenderal Kementerian Keuangan. Jurnal Akuntansi Dan Keuangan, 19(1), 13-22. https://doi.org/10.9744/jak.19.1.13-22

Hesford, J. W., Lee, S.-H. (Sam), Stede, W. A. Van Der, \& Young, M. (2007). Handbook of Management Accounting Research Volume 1.

Hidayati, Y. I., \& Djuminah. (2013). Attitudes, Subjective Norm, Pengaruh Sosial terhadap Niat Penggunaan Sistem Informasi Keuangan Daerah (SKPD) Kota Madiun. Jurnal Akuntansi Dan Pendidikan, 71-85.

Ismail, M., Maret, U. S., Widagdo, A. K., Maret, U. S., Widodo, A., \& Maret, U. S. (2016). Sistem akuntansi pengelolaan dana desa. Jurnal Ekonomi Dan Bisnis, 19(2), 322-340.

Istiyanto, S. (2016). Kerugian Daerah, Kesejahteraan Masyarakat dan Opini Pemeriksaan atas Laporan Keuangan Pemerintah Daerah di Indonesia. Jurnal Akuntansi Dan Bisnis, 16(2), 135-148. 
Juliana, P., \& Widhianningrum, P. (2017). Akuntabilitas Anggaran Pendapatan dan Belanja Desa Garon Kecamatan Kawedanan Kabupaten Magetan. Jurnal Akuntansi Dan Pendidikan, 6(2), 169-183.

Julianry, A., Syarief, R., \& Affandi, M. J. (2017). Pengaruh Pelatihan dan Motivasi terhadap Kinerja Karyawan serta Kinerja Organisasi Kementerian Komunikasi dan Informatika. Jurnal Aplikasi Bisnis Dan Manajemen, 3(2), 226-245. https://doi.org/10.17358/JABM.3.2.226

Junaidi. (2010). Asimetri pada Flypaper Effect: Bukti Empiris Pemanfaatan Dana Alokasi Umum pada Pemerintah Daerah di Indonesia. Jurnal Akuntansi Dan Keuangan, 45-55.

Kamaludin, \& Usman, B. (2018). Policy Regime and Policy Change: Comparing the Phenomenon of Local Government Before and After Regional Autonomy. Jurnal Ekonomi Dan Bisnis, 21(1), 1-22.

Kirana, M., \& Saleh, S. (2011). Public Sector Efficiency In Indonesia (Fiscal Decentralization Era, 2001 - 2008). Journal of Indonesian Economy and Business, 26(1), 103-128.

Kurniati, E., Asmony, T., \& Santoso, D. (2017). Kemelut penatausahaan aset tetap (dulu hingga kini). Jurnal Akuntansi Multiparadigma, 8(62), 540-558.

Kurrohman, T. (2013). Evaluasi penganggaran berbasis kinerja melalui kinerja keuangan yang berbasis. Jurnal Dinamika Akuntansi, 5(1), 1-11.

Malik, A. S. (2014). Analisis Konvergensi antar provinsi di Indonesia Setelah Pelaksanaan Otonomi Daerah Tahun 2001-2012. Journal Economic and Policy, 7(1), 92-101. https://doi.org/10.15294/jejak.v7i1.3846

Matalia. (2012). Pengaruh Kepemimpinan dan Hubungan Kerja terhadap Pengembangan Karir dan Kepuasan Kerja Pegawai di Kantor Sekretariat Pemerintah Daerah Provinsi Bali. Jurnal Manajemen, Strategi Bisnis, Dan Kewirausahaan, 6(2), 185-194.

Mudhofar, K., \& Tahar, A. (2016). Pengaruh Desentralisasi Fiskal dan Kinerja Terhadap Akuntabilitas Pelaporan Keuangan Pemerintah Daerah di Indonesia: Efek Moderasi dari Kinerja. Jurnal Akuntansi Dan Investasi, 17(2), 176-185. https://doi.org/10.18196/jai.2016.0053.176-185

Muhtar, Putro, D. A., \& Sutaryo. (2017). Penentu transparansi pemerintah daerah: sebuah studi pada pemerintah daerah di Indonesia. Jurnal Akuntansi Dan Auditing Indonesia, 21(2).

Nikijuluw, R. (2012). Analisis Pengaruh Transfer Pemerintah Pusat terhadap Upaya Pemungutan Pajak Kabupaten / Kota di Indonesia. Jurnal Ekonomi Dan Pembangunan Indonesia, 12(2), 168-191.

Nor, W. (2012). Penerapan Balanced Scorecard pada Pemerintah Daerah. Jurnal Ilmiah Akuntansi Dan Bisnis, 7(2), 280-292.

Novriansa, A., \& Sugiyanto, B. R. L. (2016). Role Conflict and Role Ambiguity on Local Government Internal Auditors: The Determinant and Impacts. Journal of Indonesian Economy and Business, 31(1), 63-80.

Nugraheni, A. C., \& Murtini, H. (2015). Determinan Kinerja Manajerial Satuan Kerja Perangkat Daerah Kabupaten Banjarnegara. Jurnal Dinamika Akuntansi, 7(2), 129137.

Nugroho, T. R., \& Prasetyo, N. E. (2018). Pengaruh Karakteristik Pemerintah Daerah terhadap Kinerja Keuangan Pemerintah Daerah Kabupaten dan Kota di Jawa Timur. Jurnal Akuntansi Dan Pendidikan, 7(1), 27-34.

Nuraeni, U. (2017). Gambaran Kinerja dan Keterikatan Kerja pada Pegawai Pengelola Barang/Jasa Pemerintah. Jurnal Akuntansi, 1(2), 473-480. 
Nurhidayati, L. L., \& Yaya, R. (2013). Alokasi Belanja Modal untuk Pelayanan Publik: Praktik di Pemerintah Daerah. Jurnal Akuntansi Dan Auditing Indonesia, 17(2), 102114.

Octariani, D., Akram, \& Animah. (2017). Anggaran Berbasis Kinerja, Sumber Daya Manusia dan Kualitas Anggaran SKPD (Suatu Pengujian Struktural). Riset Akuntansi Dan Keuangan Indonesia, 2(1), 27-41.

Oktafien, S. (2018). Peran Persepsi Lingkungan Kerja dan Disiplin Kerja terhadap Kinerja Pegawai (Studi pada PNSD Se-SKPD/Unit Kerja di Lingkungan Pemerintah Kota BDG). Jurnal Akuntansi, 2(1), 440-452.

Pahlevi, A. R., \& Setiawan, D. (2017). Apakah Karakteristik Kepala Daerah berdampak terhadap Kinerja Pemerintahan? Jurnal Akuntansi Multiparadigma, 8(36), 571-582.

Pandansari, T. (2016). Tingkat Ketergantungan, Kompleksitas Pemerintah, dan Tingkat Pengungkapan Laporan Keuangan Pemerintah Daerah. Jurnal Ekonomi Dan Bisnis, 19(3), 463-485.

Parananda, B. H. (2016). Pengaruh Pemahaman Akuntansi, Tingkat Pendidikan, dan Lama Masa Kerja terhadap Penerapan Sistem Akuntansi Pemerintah Daerah (SAPD) pada Kabupaten Ngawi dan Kabupaten Pacitan. Jurnal Akuntansi Dan Bisnis, 16(1), 47-59.

Prabowo, E. D. (2016). Pengaruh Faktor Politik dan Karakteristik Pemerintah Daerah terhadap Alokasi Belanja Hibah pada Pemerintah Kota/Kabupaten di Indonesia TA 2015. Jurnal Akuntansi Dan Bisnis, 16(2), 97-107.

Pramuka, B. A. (2010). Flypaper Effect pada Pengeluaran Pemerintah Daerah di Jawa. Jurnal Ekonomi Pembangunan, 11(1), 1-12.

Prastiwi, D., \& Satyawan, M. D. (2014). Identifikasi Permasalahan Tunggakan Pajak Bumi dan Bangunan (PBB) di Wilayah Kabupaten Madiun. Jurnal Ilmiah Akuntansi Dan Bisnis, 9(2), 73-83.

Pratomo, D. (2016). Pengaruh Kompetensi, Kompleksitas Tugas, dan Tekanan Anggaran Waktu terhadap Kualitas Audit Internal Pemerintah Daerah. Jurnal Akuntansi Dan Bisnis, 16(2), 122-133.

Purbasari, H., \& Bawono, A. D. B. (2017). Pengaruh Desentralisasi Fiskal, Sistem Pengendalian Internal dan Kinerja Pemerintah Daerah terhadap Akuntabilitas Laporan Keuangan. Riset Akuntansi Dan Keuangan Indonesia, (8), 102-108.

Purwanti, L. (2018). Apakah Standar Akuntansi Pemerintahan Berbasis Akrual Membawa Berkah? Jurnal Akuntansi Multiparadigma, 9(1), 173-191.

Purwanto, A. (2016). Pengaruh Kondisi Keuangan dan Politik terhadap Perubahan Anggaran pada Pemerintah Daerah di Indonesia. Jurnal Akuntansi Dan Bisnis, 16(2), 87-96.

Putri, N. E., \& Fanani, Z. (2018). Strategy mempertahankan Harta anak Bangsa Pasca Tax Amnesty. Media Riset Akuntansi Auditing Dan Informasi, 18(1), 101-114.

Rahayu, F. I. S. (2018). Determinan Kualitas Opini Audit Pemerintah Daerah. Jurnal Akuntansi Multiparadigma, 9(2), 267-279.

Rahman, A. (2011). Evaluasi Kesuksesan E-Government: Studi di Kabupaten Sleman dan Kabupaten Tulungagung. Jurnal Akuntansi Dan Auditing Indonesia, 15(2), 190203.

Rahmanti, V. N., \& Prastiwi, A. (2011). Analisis Faktor-Faktor yang Menyebabkan Laporan Keuangan Pemerintah Daerah Beropini Disclaimer. Jurnal Akuntansi Multiparadigma, 2(2), 186-368.

Randa, F., \& Daromes, F. E. (2014). Transformasi Nilai Budaya Lokal dalam Membangun Akuntabilitas Organisasi Sektor Publik. Jurnal Akuntansi Multiparadigma, 5(3), 345-510. 
Ratmono, D., \& Pradopowati, A. (2016). Determinan Fraud Belanja Bantuan Sosial. Jurnal Akuntansi Multiparadigma, 7(3), 328-340.

Ratmono, D., \& Rochmawati, A. (2018). Determinan Optimalisasi Penggunaan Aset Tetap Pemerintah Daerah. Jurnal Akuntansi Multiparadigma, (2015).

Ratmono, D., \& Suryani, R. (2016). Anteseden dan konsekuensi keberhasilan implementasi performance-based budgeting pada pemerintah daerah. Jurnal Akuntansi Dan Auditing Indonesia, 20(1).

Ratnafuri, K., \& Herawati, N. (2012). Malpraktek Pemotongan dan Pemungutan Pajak oleh Bendaharawan Pemerintah. Jurnal Akuntansi Multiparadigma, 3(3), 334-501.

Rimawati, Y. (2012). Keberhasilan Implementasi Elektronic Government Berdasarkan Persepsi Pengguna. Jurnal Akuntansi Multiparadigma, 3(2), 161-331.

Riyardi, A., \& Widojono. (2011). Analisis Efisiensi, Efektivitas dan responsibilitas Kapasitas Sumber Daya Manusia Pemerintah Daerah Sragen. Journal Economic and Policy, 4(September), 91-101.

Saraswati, M. T., Budiwibowo, S., \& Sulistyowati, N. W. (2017). Analisis Perlakuan Akuntansi Aset Tetap dalam Penyusunan Neraca Pada Pemerintahan Kabupaten Madiun. Jurnal Akuntansi Dan Pendidikan, 6(2), 152-167.

Sarkoro, H., \& Zulfikar. (2016). Dana Alokasi Khusus dan Pendapatan Asli Daerah terhadap Indeks Pembangunan Manusia (Studi Empiris pada Pemerintah Provinsi se-Indonesia Tahun 2012-2014). Riset Akuntansi Dan Keuangan Indonesia, 1(2010), 54-63.

Satriayaja, J., Handajani, L., \& Putra, I. N. N. A. putra. (2017). Turbulensi dan legalisasi kleptokrasi dalam pengelolaan keuangan desa. Jurnal Akuntansi Multiparadigma, 244-261.

Satrio, M. D., Yuhertiana, I., \& Hamzah, A. (2016). Implementasi Standar Akuntansi Pemerintah Berbasis Akrual di Kabupaten Jombang. Jurnal Akuntansi Dan Keuangan, 18(1), 59-69. https:// doi.org/10.9744/jak.18.1.59-70

Setiawan, D., \& Setyorini, E. (2018). Kajian Ekonomi \& Keuangan Dampak Pemilihan Kepala Daerah terhadap Alokasi Belanja. Kajian Ekonomi Dan Keuangan, 2(2).

Setiawaty, A. (2013). Audit quality of government auditor. Jurnal Akuntansi Multiparadigma, 4(89), 330-507.

Setiono, B., \& Hapsoro, D. (2016). Financial Report and Public Accountability Culture in Indonesia. Jurnal Akuntansi Dan Auditing Indonesia, 20(1).

Setyaningrum, D., \& Syafitri, F. (2012). Analisis pengaruh karakteristik pemerintah daerah terhadap tingkat pengungkapan laporan keuangan. Jurnal Akuntansi Dan Keuangan Indonesia, 9(2), 154-170.

Shandi, E. D., Hasthoro, H. A., \& Putri, W. H. (2016). Kinerja Manajerial Pemerintah daLAM Perspektif Islam ( Studi pada Pemerintah Kota Yogyakarta ). Jurnal Kajian Ekonomi Dan Bisnis Islam, 9(1), 139-158.

Shariha, J. (2014). The Role of Audit Bureau In Eradicating Financial Corruption in Libya. Jurnal Akuntansi Multiparadigma, 5(1), 1-169.

Siddi, P. (2016). Peran Karakteristik Keuangan dan Opini dalam Meningkatkan Kinerja Penyelenggaraan Pemerintahan Daerah. Jurnal Akuntansi Multiparadigma, 7(3), 425-442.

Sitepu, B. (2017). Analisis Anggaran Pemerintah ( APBN dan APBN-P) dalam Perspektif Demokrasi Multipartai dan Koalisi. Jurnal Ekonomi Dan Pembangunan Indonesia, 17(1), 28-43.

Soepriyanto, G., \& Aristiani, R. (2011). Evaluasi Pengungkapan Laporan Keuangan Daerah di Situs Internet: Studi pada Pemerintah Daerah Indonesia, 2(1), 192-201.

Sofyani, H., \& Akbar, R. (2013). Hubungan Faktor Internal Institusi dan Implementasi 
Sistem Akuntabilitas Kinerja Instansi Pemerintah (SAKIP) di Pemerintah Daerah. Jurnal Akuntansi Dan Keuangan Indonesia, 10(2), 184-205.

Sofyani, H., \& Akbar, R. (2015). Hubungan Karakteristik Pegawai Pemerintah Daerah dan Iplementasi Sistem Pengukuran Kinerja: Perspektif Ismorfisma Institusional. Jurnal Akuntansi Dan Auditing Indonesia, 19(2), 153-173.

Sofyani, H., \& Prayudi, M. A. (2018). Implementasi Anggaran Berbasis Kinerja di Pemerintah Daerah dengan Akuntabilitas Kinerja “A." Jurnal Ilmiah Akuntansi Dan Bisnis, 13(1), 54-64.

Soleman, R. (2013). Pengaruh Pengendalian Internal dan Good Corporate Governance terhadap Cegahan Fraud. Jurnal Akuntansi Dan Auditing Indonesia, 17(1), 57-74.

Solikin, A. (2016). Analisis Flypaper Effect pada Pengujian Pengaruh Dana Alokasi Umum (DAU), Pendapatan Asli Daerah (PAD), dan Sisa Lebih Penghitungan Anggaran (SILPA) terhadap Belanja Pemerintah Daerah di Indonesia (Studi Tahun 2012-2014). Jurnal Akuntansi Dan Bisnis, 16(1), 11-25.

Subadriyah. (2017). Flypaper Effect: Sebelum dan Sesudah Penerapan Standar Akuntansi Pemerintahan Akrual. Jurnal Akuntansi Multiparadigma, 8(3), 427-611.

Subowo, \& Wati, E. R. (2010). Hubungan antara PAD dan Dana Perimbangan dengan Belanja Modal Pemda Kudus. Jurnal Dinamika Akuntansi, 2(2), 73-82.

Sumando, E., Hamiyani, F. D., \& Purba, I. D. (2018). Pengembangan Metode Cash Forecasting Pemerintah: Studi Kasus Saldo Kas Pemerintah 2009-2011. Kajian Ekonomi Dan Keuangan.

Surastiani, D. P., \& Handayani, B. D. (2015). Analisis Faktor-Faktor yang Mempengaruhi Kualitas Informasi Laporan Keuangan Pemerintah Daerah. Jurnal Dinamika Akuntansi, 7(2), 139-149.

Surepno. (2015). Kunci Sukses dan peran Strategis Implementasi Akuntansi Berbasis Akrual. Jurnal Dinamika Akuntansi, 7(2), 119-128.

Suryarini, T., \& Anwar, S. (2010). Danpak Kebijakan Sunset Policy terhadap Kemauan Membayar Pajak pada KPP Semarang Barat. Jurnal Dinamika Akuntansi, 2(2), 135146.

Suryono, E., \& Chariri, A. (2016). Sikap, Norma Subjektif, dan Intensi Pegawai negeri Sipil untuk Mengadukan Pelanggaran (Whistle-blowing). Jurnal Akuntansi Dan Keuangan Indonesia, 13(1), 102-116.

Sutaryo, \& Sinaga, D. (2018). Government Internal Control System Maturity : The Role of Internal Guidance and External Control of Local Government in Indonesia. Jurnal Akuntansi Dan Investasi, 19(1), 24-35. https:// doi.org/10.18196/jai.190189

Taufik, M. G., \& Bandi. (2015). Karakteristik Pemerintah Daerah Karakteristik Kepala Daerah, Karakteristik Inspektorat Daerah dan ketepatan Waktu Penyampaian Laporan Keuangan Pemerintah Daerah Indonesia. Jurnal Akuntansi Dan Bisnis, 15(1), 65-73.

Terminanto, A. A., \& Rama, A. (2017). Pembiayaan Bank Syariah Terhadap Pertumbuhan Ekonomi: Studi Kasus Data Panel Provinsi di Indonesia. Jurnal Kajian Ekonomi Dan Bisnis Islam, 10(1).

Tresnawati, E. F., \& Setiawan, A. R. (2013). Ada apa dengan sap (aads) 1 akrual 2 ? Jurnal Akuntansi Multiparadigma, 4(2), 165-329.

Trisaptya, Y., Perdana, H. D., \& Sulardi. (2016). Evaluasi Akuntabilitas Laporan Keuangan Pemerintah Daerah di Indonesia (Studi Empiris pada Pemerintah Kabupaten/Kota di Provinsi Jawa Tengah). Jurnal Akuntansi Dan Bisnis, 16(1), 7586.

Ulum, A. S. (2011). Peran Pengukuran Kinerja dalam Mendukung Good Governance dalam Perspektif Agency Theory. Jurnal Dinamika Akuntansi, 3(1), 60-66. 
Usman, Sunandar, \& Farida, I. (2014). Analisis Faktor-Faktor Yang Mempengaruhi Implementasi Akuntansi Akrual pada Entitas Pemerintah Daerah. Jurnal Akuntansi Dan Investasi, 15(2).

Verawaty, Jaya, A. K., \& Megawati. (2016). Determinan Timeliness Penetapan APBD Pemerintah. Jurnal Akuntansi Multiparadigma, 7(3), 504-514.

Wahyuni, S. (2013). Konsentrasi Partai Politik dan Opini Laporan Keuangan daerah: kegagalan Resep ata Substansi? Jurnal Siasat Bisnis, 17(1), 107-116.

Wibisono, A., Faisal, F., \& Fuad, F. (2018). Determinan Intensi Pelaporan Pelanggaran : Studi Empiris Pada Direktorat Jenderal Kekayaan Negara. Jurnal Ekonomi Dan Bisnis, 21(2), 203-218.

Widagdo, A. K., \& Munir, M. B. (2017). Profil Kepala Daerah dan Kinerja Penyelenggaraan Pemerintah Daerah. Jurnal Ekonomi Dan Bisnis, 20(2), 303-330.

Wijaya, A. H. C., \& Akbar, R. (2013). The Influence of Information, Organizational Objectives and Targets, and External Pressure Towards the Adoption of Performance Measurement System in Public Sector. Journal of Indonesian Economy and Business, 28(1), 62-83.

Wijayanti, P., \& Hanafi, R. (2018). Pencegahan Fraud pada Pemerintahan Desa. Jurnal Akuntansi Multiparadigma, 9(2), 331-345.

Winoto, A. H., \& Falikhatun. (2015). Indikasi Penyalahgunaan Discretionary Fund dalam Anggaran Pendapatan dan Belanja Daerah Menjelang Pemilukada 2015. Jurnal Akuntansi Dan Keuangan Indonesia, 12(1), 75-91.

Yanida, M., Sudarma, M., \& Rahman, A. F. (2013). Pengaruh Partisipasi Anggaran terhadap Kinerja aparatur Pemerintah. Jurnal Akuntansi Multiparadigma, 4(3), 330507.

Yuhertiana, I., Pranoto, S., \& Priono, H. (2012). Perilaku Disfungsional pada Siklus Penganggaran Pemerintah: Tahap Perencanaan Anggaran. Jurnal Akuntansi Dan Auditing Indonesia, (Bissessar 2010).

Yuliani, N. L., \& Susanto, B. (2018). Partisipasi Anggaran dan Kinerja Managerial di Pemerintah Daerah: Anteseden dan Pemediasi. Jurnal Akuntansi Dan Investasi, 19(1), 92-105. https://doi.org/10.18196/jai.190194

Yustrianthe, R. H. (2012). Beberapa Faktor yang Mempengaruhi Audit Judgment Auditor Pemerintah. Jurnal Dinamika Akuntansi, 4(2), 72-82.

Zamzami, F., \& Faiz, I. A. (2015). Evaluasi Implementasi Sistem Pengendalian Internal: Studi Kasus pada Sebuah Perguruan Tinggi Negeri. Jurnal Akuntansi Multiparadigma, 6(1), 1-174. https://doi.org/10.18202/jamal.2015.04.6003

Zulaikha, \& Hadiprajitno, P. th B. (2016). Faktor-faktor yang memengaruhi Procurement Fraud: Sebuah Kajian dari Perspektif Persepsian Auditor Eksternal. Jurnal Akuntansi Dan Keuangan Indonesia, 13(2), 194-220. 